\title{
Post-metamorphic carry-over effects of altered thyroid hormone level and developmental temperature: physiological plasticity and body condition at two life stages in Rana temporaria
}

\author{
Katharina Ruthsatz ${ }^{1}$ - Kathrin H. Dausmann ${ }^{1}$. Steffen Reinhardt ${ }^{1} \cdot$ Tom Robinson $^{1}$ - Nikita M. Sabatino ${ }^{2}$. \\ Myron A. Peck ${ }^{3}$. Julian Glos ${ }^{1}$
}

Received: 24 August 2019 / Revised: 3 February 2020 / Accepted: 15 February 2020 / Published online: 6 March 2020

(c) The Author(s) 2020

\begin{abstract}
Environmental stress induced by natural and anthropogenic processes including climate change may threaten the productivity of species and persistence of populations. Ectotherms can potentially cope with stressful conditions such as extremes in temperature by exhibiting physiological plasticity. Amphibian larvae experiencing stressful environments display altered thyroid hormone (TH) status with potential implications for physiological traits and acclimation capacity. We investigated how developmental temperature $\left(T_{\mathrm{dev}}\right)$ and altered TH levels (simulating proximate effects of environmental stress) influence the standard metabolic rate (SMR), body condition (BC), and thermal tolerance in metamorphic and post-metamorphic anuran larvae of the common frog (Rana temporaria) reared at five constant temperatures $\left(14-28^{\circ} \mathrm{C}\right.$ ). At metamorphosis, larvae that developed at higher temperatures had higher maximum thermal limits but narrower ranges in thermal tolerance. Mean $\mathrm{CT}_{\max }$ was $37.63{ }^{\circ} \mathrm{C} \pm 0.14$ (low TH), $36.49{ }^{\circ} \mathrm{C} \pm 0.31$ (control), and $36.43{ }^{\circ} \mathrm{C} \pm 0.68$ (high $\mathrm{TH}$ ) in larvae acclimated to different temperatures. Larvae were able to acclimate to higher $T_{\text {dev }}$ by adjusting their thermal tolerance, but not their SMR, and this effect was not impaired by altered TH levels. BC was reduced by $80 \%$ (metamorphic) and by $85 \%$ (postmetamorphic) at highest $T_{\mathrm{dev}}$. The effect of stressful larval conditions (i.e., different developmental temperatures and, to some extent, altered TH levels) on SMR and particularly on BC at the onset of metamorphosis was carried over to froglets at the end of metamorphic climax. This has far reaching consequences, since body condition at metamorphosis is known to determine metamorphic success and, thus, is indirectly linked to individual fitness in later life stages.
\end{abstract}

Keywords Thermal tolerance $\cdot$ Endocrine disruption $\cdot$ Standard metabolic rate $\cdot$ Acclimation $\cdot \mathrm{CT}_{\max } \cdot$ Thermal window . Common-garden experiment $\cdot$ Carry-over effects

\section{Introduction}

Climate change has profound and diverse effects on organisms and is altering aquatic and terrestrial systems worldwide (IPCC 2014; Deutsch et al. 2015). Changes in

Communicated by G. Heldmaier.

Katharina Ruthsatz

k.ruthsatz@web.de

1 Institute for Zoology, University of Hamburg, Martin-Luther-King-Platz 3, 20146 Hamburg, Germany

2 Department of Life Sciences, Hamburg University of Applied Sciences, Ulmenliet 20, 21033 Hamburg, Germany

3 Institute of Hydrobiology and Fisheries Science, University of Hamburg, Olbersweg 24, 22767 Hamburg, Germany temperature can prove challenging for wildlife (Rowe and Crandall 2018), particularly ectotherms whose body temperature fluctuates with environmental temperature with consequences for changes in the rates of most biochemical reactions and biological processes (Harkey and Semlitsch 1988; Zuo et al. 2012; reviewed in Little and Seebacher 2016). All animals have a thermal range of tolerance that is set by upper and lower critical threshold temperatures $\left(\mathrm{CT}_{\min }\right.$ and $\mathrm{CT}_{\max }$ ) beyond which survival is not possible (Holzman and McManus 1973; Little and Seebacher 2016). Thermal stress as a result of global warming and extreme thermal events such as heat waves could, therefore, affect the performance and fitness traits of ectotherms (reviewed in Narayan 2016).

Ectotherms may respond to stressful variation in environmental temperature by exhibiting physiological plasticity. This process can include specific types of responses, 
including heat hardening, thermal compensation, and acclimation (Bullock 1955; Prosser 1955; Hazel and Prosser 1974; Huey et al. 1999; Angilletta et al. 2006). These different forms of thermally induced plasticity allow individuals to potentially acclimate to the complex temporal or spatial heterogeneity in environmental temperatures (Angilletta 2009; Angilletta et al. 2010; Jessop et al. 2018) and increase resilience of ectothermic animals to climate change (Seebacher et al. 2015; Little and Seebacher 2016; Lillywhite 2016). A major challenge that ectotherms face in variable thermal environments is the maintenance of appropriate energy metabolism (e.g., the standard metabolic rate, SMR) (Angilletta et al. 2002; Little and Seebacher 2016) which is determined by measuring rates of $\mathrm{O}_{2}$ consumption at rest and represents the energy required to cover minimum physiological functions (Rowe et al. 1998; Beck and Congdon 2003).

Global warming also impacts wildlife in complex ways through synergistic interactions with other environmental stressors that arise either from anthropogenic activity or natural sources (Noyes et al. 2009; Narayan 2016). Sub-optimal levels of environmental factors can activate the neuroendocrine system and increase stress hormone levels (Denver 1997; Mann et al. 2009; Dantzer et al. 2014) which also target the hypothalamus-pituitary-thyroid axis, responsible for production of thyroid hormones (THs) (Carr and Patiño 2011). Stress hormones may synergize with THs resulting in increased TH production (Glennemeier and Denver 2002; Laudet 2011; Kulkarni and Buchholz 2012). In all vertebrates, THs are critical for regulating energy metabolism (Sheridan 1994; Choi et al. 2017). If the TH concentration changes due to environmental stress, a whole suite of physiological processes may be influenced (Steyermark et al. 2005; Hulbert and Else 2004). Any impact on the hypothalamus-pituitary-thyroid axis is of special concern in amphibians, as metamorphosis is mainly regulated by THs (Tata 2006; Furlow and Neff 2006). The presence of predators (Relyea 2002; Capellán and Nicieza 2007), crowding (Morey and Reznick 2001), desiccation risk (Gervasi and Foufopoulos 2008), food scarcity (Kupferberg 1997), and temperature (Smith-Gill and Berven 1979; reviewed in Ruthsatz et al. 2018a) are known to increase TH production by activating the neuroendocrine stress axis. Anuran larvae with high TH levels display increased rates of development and standard metabolism and decreased rates of growth (Rowe et al. 1998; Brown and Cai 2007), which results in shorter larval periods and a smaller size at the onset of metamorphosis (Denver 1998, 2009; Orlofske and Hopkins 2009). Whereas most environmental stressors lead to increased TH activity or production by the activation of stress hormones, a large number of aquatic contaminants have also been shown to inhibit the normal action of THs in amphibians, leading to changes in growth, development, and metabolism (reviewed in Mann et al. 2009; Kashiwagi et al. 2009; Carr and Patiño 2011). Inhibition or a decrease of TH production pathways slows the rate of development (Carr and Theodorakis 2006; Bulaeva et al. 2015) and decreases SMRs (Carr and Patiño 2011; Ortiz-Santaliestra and Sparling 2007) causing larvae to metamorphose at a larger size and older age (Shi 2000).

Metamorphosis was long thought to provide an adaptive decoupling between traits specialized for each-life-history stage in species with complex life cycles (Wilbur 1980; Moran 1994). However, an increasing number of studies are finding that larval traits can carry-over to influence postmetamorphic performance, suggesting that these life-history stages may not be free to evolve independently of each other (Crean et al. 2011). Environmental conditions experienced during the larval stage often affect development in ways that transcend the metamorphic boundary causing carry-over or latent effects on post-metamorphic phenotypes (Pechenik 2006; Räsänen et al. 2002; Gomez-Mestre et al. 2010; Yagi and Gren 2016). Larval traits that may influence juvenile fitness include morphological and physiological traits, such as larval size, develpopmental rate, and age (Ficetola and De Bernardi 2006; Crean et al. 2011; Yagi and Green 2017). Juvenile performance and, thus, survival are often associated size-dependent due to better predator avoidance, thermoregulation, and water content in individuals of larger size (John-Alder and Morin 1990; Goater et al. 1993; Beck and Congdon 2000; Alvarez and Nicieza 2002; Ruthsatz et al. 2019). Even if size at metamorphosis has been proven as a reliable fitness predictor in several studies (Berven and Gill 1983, Rana sylvatica; Berven 1990, Rana sylvatica; Goater 1994, Bufo bufo; Morey and Reznick 2001, Spea hammondii), other studies have found that much more is carried from the larval period than size (Pechenik 2006; Van Allen et al. 2010). Scott (1994) found evidence of a further mechanism increasing fitness linked to stressful larval environments in juvenile frogs: size of lipid reserves (i.e., body condition). Body condition typically is strongly correlated with body size, particularly in amphibian metamorphs (Scott et al. 2007). However, we could show that body condition and juvenile performance might be size-independent due to the altered energy allocation during metamorphic climax (Ruthsatz et al. 2019). As metamorphosis is an energy-consuming process (Sheridan and Kao 1998; Beck and Congdon 2003), it is advantageous to maintain a low SMR. Therefore, energetics (i.e., SMR and size of energy stores) at the onset and after completion of metamorphosis are important fitness proxies (Steyermark et al. 2005; Muir et al. 2014; Ruthsatz et al. 2018b). We assume that especially SMR at the onset of metamorphosis leads to carry-over effects on energy stores at the end of metamorphosis due to energy allocation during metamorphic climax.

Climate change is expected to not only result in long-term warming of aquatic habitats but also increased variability in 
temperature leading to new thermal challenges for larvae in their larval habitats (Gutiérrez-Pesquera et al. 2016) with likely impacts on growth, development, and survival (Pörtner 2001; Dalvi et al. 2009). Additional stress leading to altered TH levels, through their impact on energy metabolism, may exacerbate these thermal challenges experienced during metamorphosis (Formicki et al. 2003). Since THs have recently been shown to play a key regulatory role in thermal acclimation in fish (Little and Seebacher 2014, 2016) and very early studies suggest that at least some aspects of this pathway are conserved in amphibians (reviewed in Little and Seebacher 2016), alteration of TH status may impact acclimation capacity in larval and juvenile anurans, especially in combination with thermal stress. Although previous studies have examined the impact of stress-induced alteration of TH levels on physiological traits of anuran larvae, studies have rarely examined interactions of different stressors which are known to affect larvae in their larval habitats (Rowe et al. 1998; Rowe and Crandall 2018).

The aim of this study was to examine the interactive effects of temperature and altered TH levels on the capacity for physiological acclimation (SMR and thermal tolerance) at the onset of metamorphosis and after completion of metamorphosis in larvae and froglets of Rana temporaria. Furthermore, we tested whether the impact of altered TH levels on SMR is temperature-dependent and whether larval SMR leads to carry-over effects on juvenile body condition. For larvae acclimated to five different temperatures, we tested the following hypotheses: (1) Developmental temperature $\left(T_{\mathrm{dev}}\right)$ correlates positively with $\mathrm{CT}_{\min }$ and $\mathrm{CT}_{\max }$, and negatively with the thermal range of tolerance in larvae. (2) High and low levels of $\mathrm{TH}$, as caused by the thyroid altering effect of several environmental stressors, and increase and decrease SMR of larvae, respectively. (3) $T_{\text {dev }}$ interacts with altered TH levels and intensifies the effect of altered TH levels on physiological traits, especially at higher temperatures. (4) Effects of $T_{\mathrm{dev}}$ and TH levels persist beyond the metamorphic boundary resulting in froglets with reduced acclimation capacity to higher temperatures. (5) Since SMR affects energy allocation during metamorphic climax, larval SMR lead to carry-over effects on post-metamorphic body condition.

\section{Materials and methods}

\section{Study species and experimental design}

Rana temporaria represents the typical amphibian life history with aquatic embryonic and larval development and terrestrial froglets and frogs. It is widely distributed throughout Europe and occurs in variety of habitats and altitudes indicating a broad thermal niche. Five clutches of $R$. temporaria were obtained from the Waldpark Marienhöhe in western Hamburg (5334' 37.4" N 9०46' 57.5" E, Hamburg, Germany). Larvae were allowed to hatch and develop to developmental stage 25 (free-swimming larvae; Gosner 1960). From these larvae, 810 individuals originating from the five clutches were intermixed before allocating them randomly to 54 standard 9.51 aquaria at six different water temperatures (i.e., 9 aquaria/temperature) in a common-garden experiment. Fifteen larvae of $R$. temporaria were kept each in an aquarium filled with $8 \mathrm{~L}$ of water (initial tadpole density: 1.87 larvae/l). The experiment was conducted in two climate chambers (Weiss Umwelttechnik GmbH, 35447 Reiskirchen, Germany) with a 12-to-12 light:dark (0900 to 2100) photoperiod and an air temperature of $10 \pm 0.2{ }^{\circ} \mathrm{C}$ and $22 \pm 0.1^{\circ} \mathrm{C}$ (mean \pm SD). Water temperatures (i.e. $14,18,25,28{ }^{\circ} \mathrm{C}$ ) were achieved by indirect heating elements beneath the aquaria (Tetra GmbH, Melle, Germany, adjustable heating element, Tetra HT100, $100 \mathrm{~W}$ ) and by air temperature for 10 and $22{ }^{\circ} \mathrm{C}$. Thus, the six mean $( \pm \mathrm{SD})$ water temperatures were $10( \pm 0.2), 14( \pm 0.5), 18( \pm 0.1), 22( \pm 0.1), 25( \pm 0.2)$, and $28( \pm 0.3)^{\circ} \mathrm{C}$. At each developmental temperature, three aquaria (i.e., replicates) each were exposed to the different treatments (L-thyroxine and sodium perchlorate) and the control group (i.e., nine aquaria/temperature: $3 \times \mathrm{T} 4,3 \times \mathrm{SP}$, $3 \times$ Control).

The experiments ran for 11 weeks. All surviving larvae had reached the end of metamorphic climax at that time (Gosner 1960). Amphibian larvae were fed high-protein flaked fish food (Sera micron breeding feed for fish and amphibians, Sera, 52518 Heinsberg, Germany) and spirulina algae twice a day ad libitum. The amount of food was continuously adjusted during the entire experiment to control for differences in tadpole size and density between the aquaria, since Miyata and Ose (2012) indicated that a restricted feeding condition causes an atrophy of thyroid tissue similarly to TH agonists. The flakes were free of perchlorate according to the manufacturer. The aquaria were checked daily for dead or abnormal larvae, which were removed (Tietge et al. 2005). At $10^{\circ} \mathrm{C}$, none of the larvae survived until the onset of metamorphosis. Therefore, we refer to larvae reared in a temperature range from 14 to $28{ }^{\circ} \mathrm{C}$ hereafter (i.e., 675 individuals in 45 aquaria: 5 water temperatures $\times 3$ treatments $\times 3$ replicates/treatment $\times 15$ individuals). Hereafter, we refer to the L-thyroxine treatment as 'high TH level' treatment and to the sodium perchlorate treatment as 'low $\mathrm{TH}$ level' treatment.

\section{L-Thyroxine and sodium perchlorate exposures}

We increased internal TH levels (i.e., high TH level) by exposing larvae to $10 \mu \mathrm{g} / \mathrm{l}$ exogenous L-thyroxine (T4, IRMM468 Sigma-Aldrich, Sigma-Aldrich, St. Louis, USA), a concentration which is known to influence 
amphibian metamorphosis (Lucas and Reynolds 1967; Mann et al. 2009) and is related to increases in T4 observed in larvae responding to stress (Denver 1997, 1998). Larvae absorb exogenous T4 directly through their permeable skin (Shi 2000; Tata 2006; Coady et al. 2010). Exposing larvae to exogenous THs is an established method to simulate the proximate effects of environmental stressors on the TH system (Denver et al. 2002; Tata 2006; Denver 2009).

We used a concentration of $250 \mu \mathrm{g} / \mathrm{l}$ sodium perchlorate (SP, 99.99\% trace metals basis, 381225 Aldrich, SigmaAldrich, St. Louis, USA) to decrease internal TH levels (i.e., low TH level). This concentration of SP is within environmental ranges measured in surface and ground waters of many industrial nations (Motzer 2001; Tietge et al. 2005; Carr and Theodorakis 2006; Mukhi and Patiño 2007) and in bodies of water in which amphibians breed (Smith et al. 2001; Ortiz-Santaliestra and Sparling 2007). SP is an environmentally relevant endocrine disruptor on TH system. As a goitrogen, it inhibits TH synthesis (Ortiz-Santaliestra and Sparling 2007) resulting in inhibited amphibian metamorphosis (Tietge et al. 2005).
1960). End of metamorphic climax was defined by the complete resorption of the tail (Gosner stage 46; Gosner 1960).

The snout-vent length (SVL) of the larvae and froglets was measured with a caliper to the nearest $0.5 \mathrm{~mm}$. Specimens were dry blotted and weighed to the nearest $0.001 \mathrm{~g}$ with an electronic balance (digital gold scale, Smart Weigh).

\section{Body condition}

We estimated the body condition (i.e., energy stores) at the onset of metamorphosis by calculating the scaled mass index (SMI). The SMI accounts for the allometric relationship between mass and a body structure, and is a standardized measure of the body condition that can be directly compared among individuals (Peig and Green 2009, 2010; MacCracken and Stebbings 2012). The SMI has been previously employed as a condition index in anuran larvae (MacCracken and Stebbings 2012; Dittrich et al. 2016; Ruthsatz et al. 2018b; Ruthsatz et al. 2019). A high SMI suggests larger energy storages and, thus, a good body condition. We followed the procedure outlined by Peig and Green (2009) to calculate the SMI for each individual:

$\mathrm{SMI}=\left[\right.$ individual mass $\left.\times\left(\frac{\text { mean SVL of population }}{\text { individual SVL }}\right)^{\text {slope of regression } \log \text { mass } \sim \log \mathrm{SVL}}\right]$.

$\mathrm{T} 4$ and SP treatments were prepared in $0.1 \mathrm{~N}$ sodium hydroxide solutions (0.1 N, S2770 SIGMA, Sigma-Aldrich, St. Louis, USA) buffered with $0.1 \mathrm{~N}$ muriatic acid solutions as solvents. Solutions were added to the aquaria. To control for any effect of solvents addition, a solution of only $0.1 \mathrm{M}$ sodium hydroxide solution buffered with $0.1 \mathrm{M}$ muriatic acid solution was added to the control aquaria. Water was changed every second day and fresh SP and T4 were added, which is frequent enough to maintain a constant hormone and perchlorate level, in accordance with the standard procedure for chemical and hormonal addition (Miwa and Inui 1987; Goleman et al. 2002a, b; Iwamuro et al. 2003; RotNikcevic and Wassersug 2004; Tietge et al. 2005; OrtizSantaliestra and Sparling 2007; Bulaeva et al. 2015).

\section{Processing of specimens}

Developmental stage was determined by evaluating the status of key morphological features typical of specific developmental stages, as detailed in Gosner (1960). The developmental stage of each tadpole was recorded according to the procedure of Ortiz-Santaliestra and Sparling (2007). The age which describes the larval duration in days after hatching until the onset of metamorphosis was defined by the emergence of at least one forelimb (Gosner stage 42; Gosner
Slope is calculated from the regression of log-transformed SVL and log-transformed mass.

\section{Respiration measurements}

Respiration measurements were made at the onset of metamorphosis $(n=360)$ and at the end of metamorphic climax $(n=360)$ on eight randomly chosen larvae and froglets from each aquarium (i.e., 45 aquaria $\times 8$ individuals. No fasting prior to the respiratory measurements was needed, because larvae stop feeding due to the remodeling of mouthparts and digestive tract during metamorphosis (Hourdry et al. 1996). Oxygen consumption was measured by closed respirometry conducted between 0900 and $2100 \mathrm{~h}$ to control for the influence of natural circadian rhythms on respiration (Orlofske et al. 2017). Larvae were placed in respirometers consisting of $30 \mathrm{ml}$ beakers containing $30 \mathrm{ml}$ (minus the volume of the animals) of autoclaved tap water to exclude microbial oxygen consumption. Froglets were placed in air-filled respirometers consisting of $30 \mathrm{ml}$ beakers (minus the volume of the animals) due to their transition to lung respiration. Each respirometer was equipped with a fiber optic sensor (Oxygen Dipping Probe DP-PSt7; PreSens Precision Sensing GmbH, Regensburg, Germany) connected to a multichannel oxygen measuring system (Oxy 4 mini; PreSens Precision Sensing GmbH, Regensburg, Germany) 
and sealed with an air tight rubber plug. $\mathrm{O}_{2}$ concentration was recorded every $15 \mathrm{~s}$ and measured as $\mathrm{ml} \mathrm{O}_{2} / 1$ at ambient temperature pressure. Prior to each trial, $\mathrm{O}_{2}$-fiber optic sensors were calibrated using air-saturated water and a factory-set zero oxygen calibration point at the respective developmental temperature of measured larvae. Water temperature and continuous mixing were controlled by a waterbath. Oxygen consumption was measured for every tadpole for $20 \mathrm{~min}$ at the respective developmental temperature (i.e., $14,18,22,25$, or $28^{\circ} \mathrm{C}$ ). Empty (control) chambers were run simultaneously in every trial and values were adjusted accordingly. We ensured that less than $10 \%$ of total $\mathrm{O}_{2}$ was removed during the measurements to avoid impediment of respiration at low saturation levels. At the end of the measurements, each larva was removed and its SVL and blotted wet body mass were determined. Larvae were placed for 1 $\mathrm{h}$ in individual 11 containers at respective developmental temperature and treatment concentration for recovery before transferring them to thermal tolerance measurements. After measurements at the end of metamorphic climax, froglets were placed back in air temperature-controlled containers for further experiments.

\section{Standard metabolic rate calculations}

Prior to statistical analysis, we plotted $\mathrm{O}_{2}$ consumption of each animal over time and visually assessed activity peaks to exclude them for the determination of standard metabolic rate (SMR) (Orlofske and Hopkins 2009). The SMR was expressed in $\mathrm{ml} \mathrm{O}_{2} / \mathrm{h} / \mathrm{mg}$ wet body mass and was determined from the slope of linear least-squares regression of $\mathrm{O}_{2}$ concentration vs. time (Hasting and Burggren 1995; Rowe and Funck 2017; Ruthsatz et al. 2018c, 2019). Values for SMR and mass were log-transformed, because metabolism is a power function of mass (Orlofske and Hopkins 2009; Orlofske et al. 2017). Only the lowest $30 \%$ of the values were used to ensure that only data of resting individuals were included in analyses, thereby omitting any phases of stress, disturbance, or activity (Orlofske and Hopkins 2009; Peck and Moyano 2016; Orlofske et al. 2017; Bethge et al. 2017).

\section{Thermal tolerance}

Thermal tolerance of $R$. temporaria was evaluated when larvae reached the onset of metamorphosis (Gosner stage 42) using the critical thermal methodology (Holzman and McManus 1973). Both critical thermal minimum $\left(\mathrm{CT}_{\min }\right)$ and maximum $\left(\mathrm{CT}_{\max }\right)$ endpoints are defined as the thermal point at which locomotor activity becomes disorganized and the animal loses the ability to right itself (Lutterschmidt and Hutchison 1997; Turriago et al. 2015). A total of 450 larvae were used for determination of thermal tolerance. From each aquarium, ten larvae $\left(n=5, \mathrm{CT}_{\min }\right.$; and $\left.n=5, \mathrm{CT}_{\max }\right)$ were tested at set time intervals. $\mathrm{CT}_{\min }$ and $\mathrm{CT}_{\max }$ were determined using the dynamic method according to Cowles and Bogert (1944) and Hutchison (1961) except for the endpoint (Wu and Kam 2005). This method involves linearly decreasing (for $\mathrm{CT}_{\text {min }}$ ) or increasing (for $\mathrm{CT}_{\max }$ ) test temperatures by a specific rate until an appropriate endpoint is reached (Lutterschmidt and Hutchison 1997). Larvae were placed individually in a $250-\mathrm{ml}$ flask with $200 \mathrm{ml}$ of water which was then placed in a temperature-controlled water bath. The heating and cooling rates were $\pm 0.1^{\circ} \mathrm{C} / \mathrm{min}$, and the water temperature served as a proxy of body temperature (Hutchison 1961). The initial temperature in the water bath was set at the respective developmental temperature. In larvae, the occurrence of spasms is difficult to determine, and thus, we decided to use the loss of the righting response after being flipped on its back in the water with a probe as our criterion for the endpoint (Lutterschmidt and Hutchison 1997; $\mathrm{Wu}$ and Kam 2005) for both $\mathrm{CT}_{\min }$ and $\mathrm{CT}_{\max }$ determinations (Turriago et al. 2015). A time limit of $30 \mathrm{~s}$ between flipping the animal and righting was adopted (Layne Jr and Claussen 1982). At the end of the measurements, larvae were placed back into rearing aquaria until they completed metamorphosis. We performed a linear regression for developmental temperature and thermal tolerance (as measured by $\mathrm{CT}_{\min }, \mathrm{CT}_{\max }$, and thermal range of tolerance). The slope of the regression for $\mathrm{CT}_{\max }$ and $\mathrm{CT}_{\text {min }}$ defined the effect of developmental temperature on critical thermal limits of $R$. temporaria.

\section{Statistical analysis}

For all statistical tests R 3.4.1 (R Development Core Team 2007) for Windows was used. All plots were constructed using ggplot2 (Wickham 2009) and Adobe Illustrator CS6.

SMR and SMI data were analyzed using generalized linear mixed-effect models GLMM: glmmPQL [package MASS - generalized linear mixed model with PQL (quasilikelihood) instead maximum likelihood (Bolker et al. 2009)] using the covariate ' $T_{\mathrm{dev}}$ ', and 'treatment' ('treatment': high $\mathrm{TH}$, low $\mathrm{TH}$, and control), and the interactions of 'treatment' and ' $T_{\text {dev }}$ ' as fixed factors. To address dependencies in the data, the variable 'aquarium' was included as a random factor. The replicate unit for the GLMM analyses was the individual larvae. 'SMR $\mathrm{larvae}_{\text {, }}$, 'Body condition larvae ,' 'SMRfroglets', and 'Body condition froglets $_{\text {' were used as dependent }}$ variables in separate models. $P$ values were obtained from quasi-likelihood-ratio tests (Bolker et al. 2009). To address dependencies in the data, the variable 'aquarium' was included as a random factor. $\mathrm{N}$ refers to the total number of analyzed larvae. 
Thermal tolerance data (i.e., $\mathrm{CT}_{\min }, \mathrm{CT}_{\max }$, and 'thermal range of tolerance') were analyzed using linear mixed-effect models: lme [package lme4 - linear mixed-effect model with REML (restricted maximum likelihood) method for parameter estimation (Bates and Sarkar 2007)]. $P$ values were obtained from likelihood-ratio tests, which compared the models with the respective null-model (Crawley 2007). ' $\mathrm{CT}_{\min }$ ', ' $\mathrm{CT} \mathrm{T}_{\max }$ ', and 'thermal range of tolerance' were used as dependent variables in separate models. To address dependencies in the data, the variable 'aquarium' was included as a random factor. Residuals of each model were visually checked for normal distribution. $N$ refers to the total number of analyzed larvae.

\section{Results}

There was no consistent effect of time of day on SMR tested during this experiment. At all developmental temperatures, larvae and froglets from the low TH treatment were the largest at the onset of metamorphosis followed by control animals and larvae from the high $\mathrm{TH}$ treatment being the smallest (Table 4).

\section{Standard metabolic rate and body condition}

\section{Onset of metamorphosis}

SMR of larvae was significantly influenced by $T_{\text {dev }}$, by low TH level, and the interactive effect of both (Table 1, Fig. 1). With increasing developmental temperature, SMR increased in all treatments except of animals which were reared at $14{ }^{\circ} \mathrm{C}$ at low $\mathrm{TH}$ level and for those which were reared at $28{ }^{\circ} \mathrm{C}$ and high TH levels. However, increase of SMR with $T_{\text {dev }}$ was not linear. SMR was highest at high $T_{\text {dev }}$ except for animals reared at $14{ }^{\circ} \mathrm{C}$, whereas the interactive effect of low TH levels and $T_{\text {dev }}$ decreased SMR (Fig. 1). Animals at low TH level revealed the highest SMR at $14{ }^{\circ} \mathrm{C}$ and $28^{\circ} \mathrm{C}$, and the lowest SMR at $18^{\circ} \mathrm{C}, 22^{\circ} \mathrm{C}$, and $25^{\circ} \mathrm{C}$. In control treatment, larvae reared at $14^{\circ}, 18^{\circ}$, and $22^{\circ} \mathrm{C}$ revealed the lowest SMR, which increased significantly at $25^{\circ} \mathrm{C}$ and $28^{\circ} \mathrm{C}$. Larvae with high $\mathrm{TH}$ levels revealed the
Table 1 Effects of altered TH levels and developmental temperature on larval and juvenile standard metabolic rate $(\mathrm{ml} \mathrm{O} / 2 / \mathrm{h} / \mathrm{mg})$ and body condition (SMI) of the common frog (R. temporaria) at the onset of metamorphosis (Gosner stage 42) and after completion of metamorphosis (Gosner stage 46; Gosner 1960)

\begin{tabular}{|c|c|c|c|c|c|c|}
\hline Dependent variable & $N$ & Fixed effects & Estimates & SE & $t$ & $P$ \\
\hline \multicolumn{7}{|l|}{ GLMM } \\
\hline \multirow[t]{6}{*}{$\operatorname{SMR}_{\text {larvae }}\left(\mathrm{ml} \mathrm{O}_{2} / \mathrm{h} / \mathrm{mg}\right)$} & \multirow[t]{6}{*}{$384(45)$} & Intercept & -0.002 & 0.003 & -0.726 & 0.468 \\
\hline & & $T_{\mathrm{dev}}$ & 0.000 & 0.000 & 4.109 & $<0.001$ \\
\hline & & Low TH & 0.014 & 0.004 & 3.292 & 0.002 \\
\hline & & High TH & 0.004 & 0.004 & 0.965 & 0.339 \\
\hline & & Low $\mathrm{TH} \times T_{\mathrm{dev}}$ & -0.001 & 0.000 & -3.328 & 0.001 \\
\hline & & High $\mathrm{TH} \times T_{\mathrm{dev}}$ & -0.000 & 0.000 & -0.948 & 0.348 \\
\hline \multirow[t]{6}{*}{ Body condition $_{\text {larvae }}(\mathrm{SMI})$} & \multirow[t]{6}{*}{$582(45)$} & Intercept & 1188.271 & 43.649 & 27.223 & $<0.001$ \\
\hline & & $T_{\mathrm{dev}}$ & -39.666 & 1.988 & -19.951 & $<0.001$ \\
\hline & & Low TH & 69.209 & 1.671 & 1.122 & 0.026 \\
\hline & & High TH & -408.240 & 62.147 & -6.568 & $<0.001$ \\
\hline & & Low $\mathrm{TH} \times T_{\mathrm{dev}}$ & -13.467 & 2.809 & 0.081 & $\mathbf{0 . 0 3 0}$ \\
\hline & & High $\mathrm{TH} \times T_{\mathrm{dev}}$ & -227.100 & 28.380 & 4.744 & $<0.001$ \\
\hline \multirow[t]{6}{*}{$\mathrm{SMR}_{\text {froglets }}\left(\mathrm{ml} \mathrm{O}_{2} / \mathrm{h} / \mathrm{mg}\right)$} & \multirow[t]{6}{*}{$359(45)$} & Intercept & -0.051 & 0.007 & -1.983 & 0.048 \\
\hline & & $T_{\mathrm{dev}}$ & 0.002 & 0.000 & 5.942 & $<0.001$ \\
\hline & & Low TH & 0.019 & 0.011 & 1.759 & 0.086 \\
\hline & & High TH & 0.036 & 0.011 & 3.291 & 0.002 \\
\hline & & Low $\mathrm{TH} \times T_{\mathrm{dev}}$ & -0.001 & 0.001 & -2.216 & $\mathbf{0 . 0 3 2}$ \\
\hline & & High $\mathrm{TH} \times T_{\mathrm{dev}}$ & -0.001 & 0.001 & -3.289 & 0.002 \\
\hline \multirow[t]{6}{*}{ Body condition $_{\text {froglets }}(\mathrm{SMI})$} & \multirow[t]{6}{*}{$525(45)$} & Intercept & 791.574 & 45.826 & 17.273 & $<0.001$ \\
\hline & & $T_{\mathrm{dev}}$ & -28.292 & 2.089 & -13.539 & $<0.001$ \\
\hline & & Low TH & 111.561 & 64.877 & 1.719 & 0.003 \\
\hline & & High TH & -413.404 & 65.308 & -6.330 & $<0.001$ \\
\hline & & Low $\mathrm{TH} \times T_{\mathrm{dev}}$ & -15.071 & 2.956 & -0.713 & 0.047 \\
\hline & & High $\mathrm{TH} \times T_{\mathrm{dev}}$ & -21.090 & 2.982 & 5.052 & $<0.001$ \\
\hline
\end{tabular}

$\mathrm{T}$ and $\mathrm{P}$ for generalized linear mixed-effects models (GLMM), using 'Treatment' (i.e., high TH, low TH, and control), ' $T_{\mathrm{dev}}$ ' and the interactions of 'Treatment $\times T_{\mathrm{dev}}$ ' as fixed factors; 'aquarium' as random factor. Low TH levels $=$ SP treatment. High TH levels $=$ T4 treatment. Significance was set at $P<0.05$. Bold indicates significant $P$ values. $N(n)$ total number of studied individuals (total number of aquaria) 


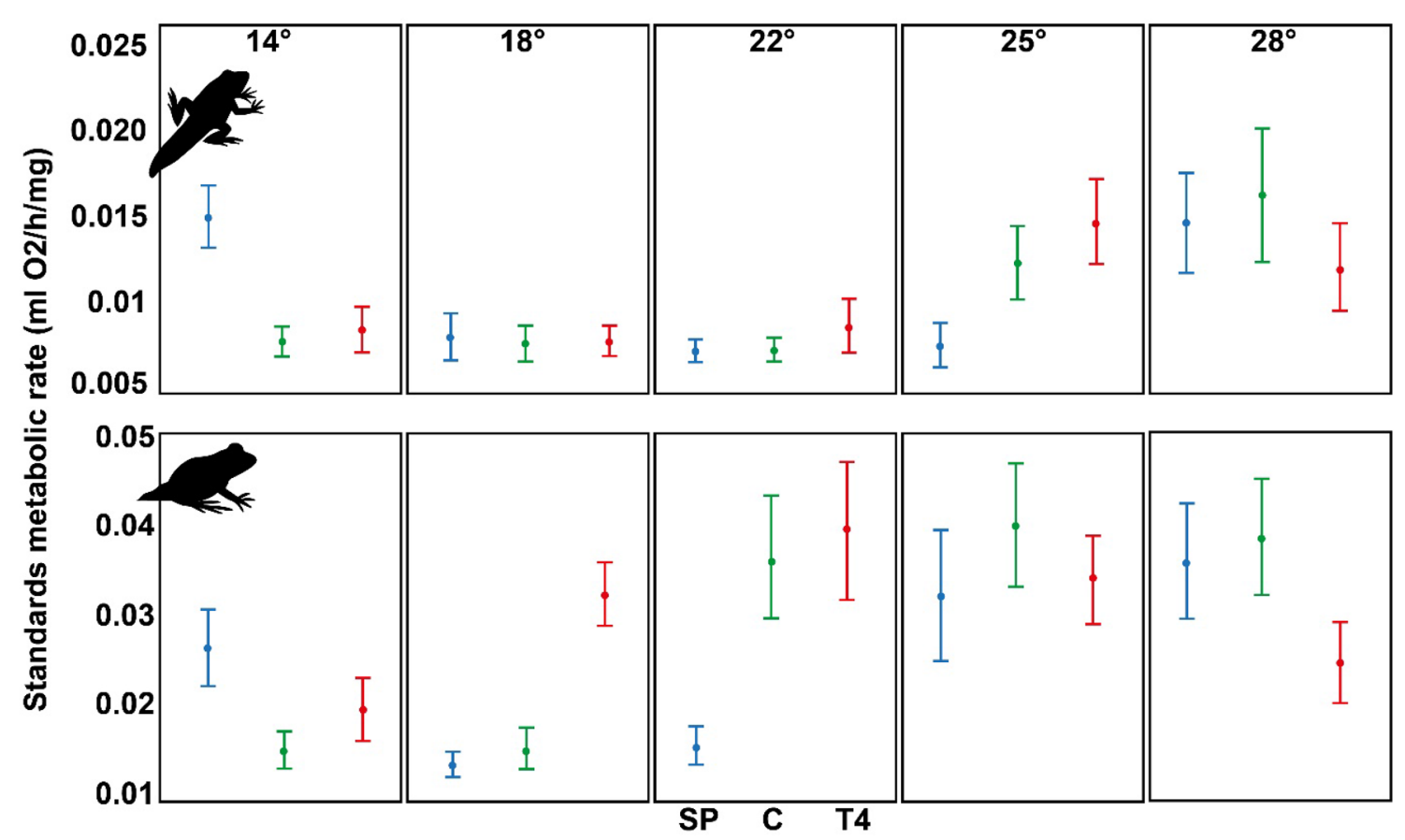

Fig. 1 Interactive effect of altered thyroid hormone levels and five developmental temperatures on SMR $\left(\mathrm{ml} \mathrm{O}_{2} / \mathrm{h} / \mathrm{mg}\right)$ in upper graphs: larvae at the onset of metamorphosis and lower graphs: froglets 7 days after completion of metamorphic climax of the common frog
(Rana temporaria). Dots show the mean body condition of each treatment; whiskers show the \pm standard error. Blue: $\mathrm{SP}=$ low $\mathrm{TH}$ levels. Green: control treatment. Red: T4=high TH level
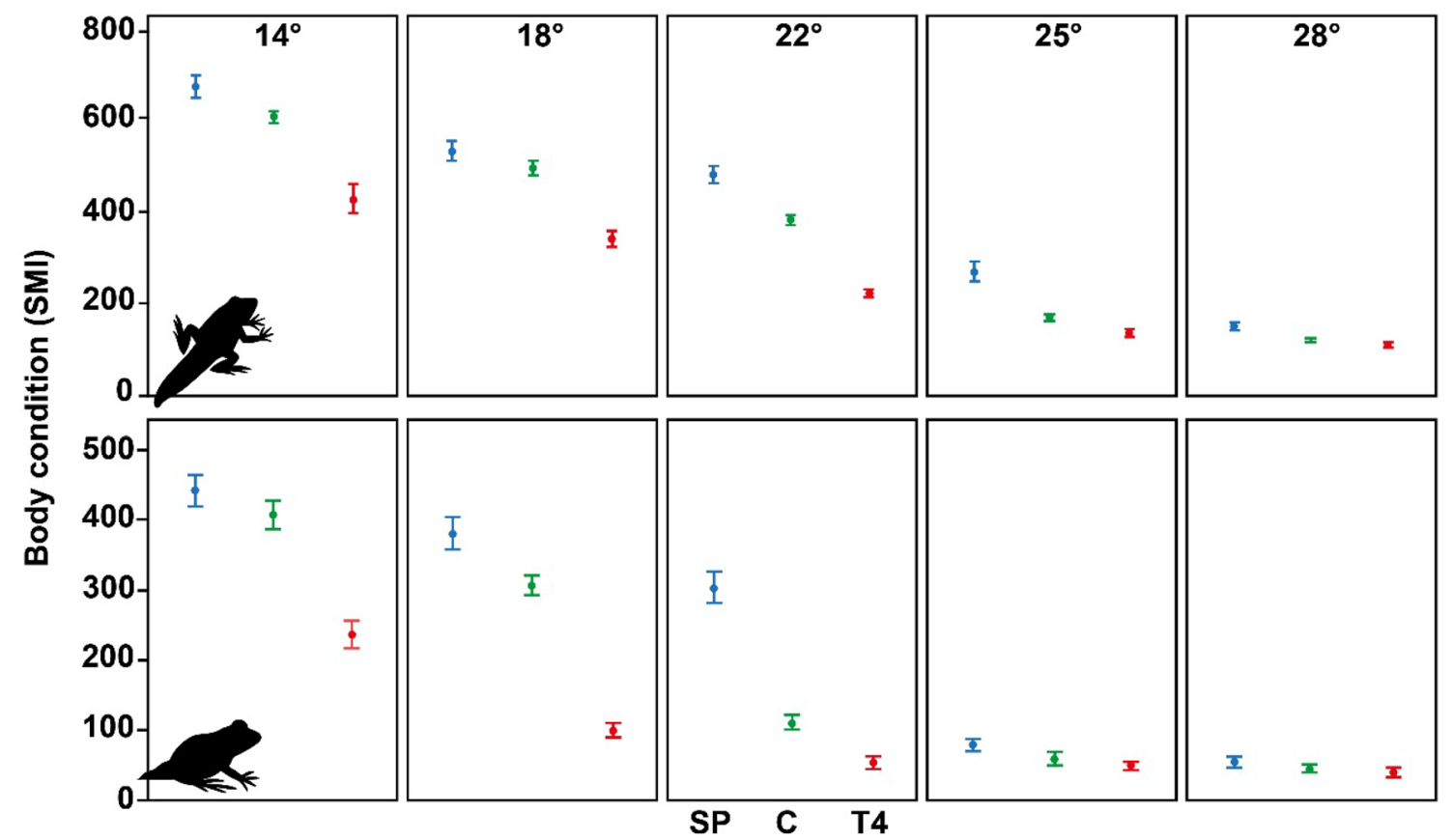

Fig. 2 Interactive effect of altered thyroid hormone levels and five developmental temperatures on body condition in upper graphs: larvae at the onset of metamorphosis and lower graphs: froglets 7 days after completion of metamorphic climax of the common frog (Rana

temporaria). Body condition was determined by the scaled mass index (SMI). Dots show the mean body condition of each treatment; whiskers show the \pm standard error. Blue: $\mathrm{SP}=$ low $\mathrm{TH}$ levels. Green: $\mathrm{C}=$ Control treatment. Red: $\mathrm{T} 4=$ high $\mathrm{TH}$ levels 
lowest SMR when reared at $18{ }^{\circ} \mathrm{C}$. Nevertheless, temperature and treatment effects on SMR were not subject to a uniform pattern.

Body condition at the onset of metamorphosis was significantly affected by the hormone treatment, $T_{\mathrm{dev}}$, and the interactive effect of both (Table 1, Fig. 2). Higher temperatures during development, high $\mathrm{TH}$ levels, and the interactive effect of both hormone treatments and higher $T_{\mathrm{dev}}$ decreased body condition, whereas low TH levels increased body condition. At all temperatures, body condition was lowest in high TH level animals and highest in SP animals. Body condition was best in larvae reared at 14 and $18{ }^{\circ} \mathrm{C}$ in all hormone treatments, whereas body condition was worst in larvae reared at highest temperature. Along the experimental range of developmental temperatures, body condition was reduced by about $80 \%$ from the lowest to the highest temperature.

\section{End of metamorphic climax}

At the end of metamorphic climax, SMR of froglets was significantly influenced by high TH levels, by $T_{\text {dev }}$, and the interactive effect of both hormone treatments and $T_{\mathrm{dev}}$ (Table 1, Fig. 1). In general, highTH levels and temperature increased SMR, whereas the interactive effect of both decreased SMR. At low TH levels, froglets revealed the lowest SMR at $18{ }^{\circ} \mathrm{C}$ and $22{ }^{\circ} \mathrm{C}$ and the highest at 14 and $28^{\circ} \mathrm{C}$. Froglets from control treatment had the lowest SMR when reared at 14 and $18{ }^{\circ} \mathrm{C}$ and the highest SMR at $28^{\circ} \mathrm{C}$. Froglets exposed to high TH levels during development had the lowest SMR at 14 and the highest SMR at highest temperatures during development. Again, treatment effects on SMR were not subject to a uniform pattern, whereas temperature effects were increasing from 18 to $28^{\circ} \mathrm{C}$. SMR was higher after the completion of metamorphosis than at the onset of metamorphosis. However, temperature and treatment effects were subject to a uniform pattern at both life stages.

Body condition of newly metamorphosed froglets was affected by $T_{\mathrm{dev}}$ and altered TH levels and the interactive effect of higher temperatures and altered TH levels (Table 1, Fig. 2). In particular, higher temperatures during development, high TH levels, and the interactive effect of both hormone treatments and higher $T_{\mathrm{dev}}$ decreased body condition, whereas low TH levels increased body condition. At all temperatures, body condition was lowest in high $\mathrm{TH}$ level animals and highest in low TH level animals. Body condition was best in larvae reared at 14 and $18{ }^{\circ} \mathrm{C}$ in all hormone treatments, whereas body condition was worst in larvae reared at highest temperature. Along the experimental range of developmental temperatures, body condition
Table 2 Effects of altered TH levels and developmental temperature on larval thermal tolerance (as measured by $\mathrm{CT}_{\text {min }}, \mathrm{CT}_{\text {max }}$, and thermal range of tolerance) in larvae of the common frog $(R$. temporaria) at the onset of metamorphosis (Gosner stage 42; Gosner 1960)

\begin{tabular}{lllrrrrr}
\hline Dependent variable & $N$ & Fixed effects & Estimate & SE & Chi $^{2}$ & $d f$ & $P$ \\
\hline LMM & & & & & & & \\
$\mathrm{CT}_{\text {min }}\left({ }^{\circ} \mathrm{C}\right)$ & \multirow{2}{*}{$450(45)$} & Intercept & 1.01 & 0.41 & 21.418 & 2 & $<\mathbf{0 . 0 0 1}$ \\
& & $T_{\text {dev }}$ & -0.11 & 0.59 & 113.29 & 1 & $<\mathbf{0 . 0 0 1}$ \\
& & Low TH & -0.05 & 0.59 & 21.41 & 2 & $<\mathbf{0 . 0 0 1}$ \\
& & High TH & 0.22 & 0.01 & 21.41 & 2 & $<\mathbf{0 . 0 0 1}$ \\
& & Low TH $\times T_{\text {dev }}$ & 0.01 & 0.02 & 1.63 & 2 & 0.441 \\
$\mathrm{CT}_{\text {max }}\left({ }^{\circ} \mathrm{C}\right)$ & High TH $\times T_{\text {dev }}$ & -0.01 & 0.02 & 1.63 & 2 & 0.441 \\
& \multirow{4}{*}{$450(45)$} & Intercept & 24.20 & 1.83 & 3.59 & 2 & 0.166 \\
& & $T_{\text {dev }}$ & -0.36 & 2.60 & 76.19 & 1 & $<\mathbf{0 . 0 0 1}$ \\
& & Low TH & -1.29 & 2.60 & 3.59 & 2 & 0.166 \\
& & High TH & 0.57 & 0.08 & 3.59 & 2 & 0.166 \\
Thermal range of tolerance & Low TH $\times T_{\text {dev }}$ & 0.05 & 0.11 & 0.40 & 2 & 0.818 \\
& & High TH $\times T_{\text {dev }}$ & 0.06 & 0.11 & 0.40 & 2 & 0.818 \\
& & Intercept & 23.19 & 1.84 & 1.40 & 2 & 0.495 \\
& & $T_{\text {dev }}$ & -0.24 & 2.61 & 45.34 & 1 & $\mathbf{0 . 0 0 1}$ \\
& & Low TH & -1.24 & 2.61 & 1.40 & 2 & 0.495 \\
& & High TH & 0.35 & 0.08 & 1.40 & 2 & 0.495 \\
& & Low TH $\times T_{\text {dev }}$ & 0.04 & 0.11 & 0.47 & 2 & 0.789 \\
& & High TH $\times T_{\text {dev }}$ & 0.07 & 0.11 & 0.47 & 2 & 0.789 \\
\hline
\end{tabular}

$\mathrm{Chi}^{2}$ and $\mathrm{P}$ for linear mixed-effects models (LMM), using 'Treatment' (i.e., high TH, low TH, and control), ' $T_{\text {dev }}$ ' and the interactions of 'Treatment $\times T_{\text {dev }}$ ' as fixed factors; 'aquarium' as random factor. Low TH levels $=$ SP treatment. High TH levels $=\mathrm{T} 4$ treatment. Significance was set at $P<0.05$. Bold indicates significant $P$ values. $N(n)$ total number of studied individuals (total number of aquaria) 
Table 3 Linear regressions of critical thermal limits (as measured by $\mathrm{CT}_{\min }$ and $\mathrm{CT}_{\max }$ ) with developmental temperature in $R$. temporaria larvae

\begin{tabular}{lllll}
\hline \multirow{2}{*}{$\begin{array}{l}\text { Dependent } \\
\text { variable }\end{array}$} & Treatment $(N)$ & \multicolumn{3}{c}{ Developmental temperature $\left({ }^{\circ} \mathrm{C}\right)$} \\
\cline { 3 - 5 } & & Slope & $\mathrm{SE}_{\text {Slope }}$ & $R^{2}$ \\
\hline $\mathrm{CT}_{\text {min }}$ & Low TH (75) & 0.24 & 0.007 & $\mathbf{0 . 9 2 8}$ \\
& Control (75) & 0.22 & 0.006 & $\mathbf{0 . 9 6 9}$ \\
& High TH (75) & 0.20 & 0.009 & $\mathbf{0 . 8 0 1}$ \\
$\mathrm{CT}_{\text {max }}$ & Low TH (75) & 0.58 & 0.023 & $\mathbf{0 . 8 9 5}$ \\
& Control (75) & 0.57 & 0.084 & $\mathbf{0 . 3 9 4}$ \\
& High TH (75) & 0.63 & 0.044 & $\mathbf{0 . 7 3 8}$ \\
\hline
\end{tabular}

Significance was set at $P<0.05 . N=75$. Low TH levels $=$ SP treatment. High TH levels $=$ T4 treatment. $P$ was $<0.001$ for all linear regressions

was reduced by about $85 \%$ from the lowest to the highest temperature. Body condition was lower after the completion of metamorphosis than at the onset of metamorphosis. Temperature and treatment effects were subject to a uniform pattern at both life stages.

\section{Thermal tolerance at the onset of metamorphosis}

The results for linear regressions show a significant relation between thermal limits (i.e., $\mathrm{CT}_{\min }$ and $\mathrm{CT}_{\max }$ ) and $T_{\text {dev }}$. $\mathrm{CT}_{\min }$ and $\mathrm{CT}_{\max }$ increased significantly with increasing developmental temperature except for larvae reared at $28^{\circ} \mathrm{C}$ (Tables 2, 3). For every $1{ }^{\circ} \mathrm{C}$ increase in $T_{\text {dev }}$, the $\mathrm{CT}_{\min }$ and $\mathrm{CT}_{\text {max }}$ increased by $0.24{ }^{\circ} \mathrm{C}$ and $0.58{ }^{\circ} \mathrm{C}$, respectively, in the low $\mathrm{TH}$ treatment, by $0.22{ }^{\circ} \mathrm{C}$ and $0.57{ }^{\circ} \mathrm{C}$ in the control treatment, and by $0.20{ }^{\circ} \mathrm{C}$ and $0.63{ }^{\circ} \mathrm{C}$ in the high $\mathrm{TH}$ treatment. Slopes from linear regressions revealed a greater effect of $T_{\mathrm{dev}}$ on $\mathrm{CT}_{\max }$ than on $\mathrm{CT}_{\min }$ within all hormone treatments. TRT increased at higher temperatures as $\mathrm{CT}_{\text {min }}$ increased less than $\mathrm{CT}_{\text {max }}$ at higher temperatures. $\mathrm{CT}_{\min }, \mathrm{CT}_{\max }$, and TRT were significantly affected by $T_{\text {dev }}$ (Table 2), whereas only $\mathrm{CT}_{\text {min }}$ was significantly decreased and increased by low and high TH treatment, respectively (Table 2).

\section{Discussion}

The capacity for species to express developmental (i.e., in age and size at metamorphosis) and physiological plasticity (i.e., in thermal tolerance and energetics) in response to temperature change is expected to help ectothermic species such as amphibians coping with some of the major drivers of biodiversity loss, such as climate-driven warming and other natural and anthropogenic environmental stressors (reviewed in Nowakowski et al. 2018; Seebacher et al. 2015). The interactions of warmer and more variable temperatures and different stressors are not well known (Boone et al. 2007; Polo-Cavia and Gomez-Mestre 2017) and knowledge on their impact on amphibian declines is still rare (Blaustein et al. 2011). Our results suggest that both larvae and froglets 7 days after completion of metamorphosis of R. temporaria are not able to acclimate to higher developmental temperatures by adjusting their maintenance energy costs (i.e., SMR) and that this capacity is impaired by the interaction between higher temperature and altered $\mathrm{TH}$ status to some extent as often elicited by environmental stressors. However, larvae at the onset of metamorphosis were able to acclimate to increased developmental temperature by increasing their thermal limits and broadened their range in thermal tolerance. The capacity for physiological plasticity and body condition, however, decreased at higher temperatures, an effect which persisted across the metamorphic boundary resulting in froglets with highly reduced body condition. We consequently demonstrated that larval traits can carry-over to influence post-metamorphic performance, suggesting that life-history stages may not evolve independently.

\section{Altered TH levels and higher temperatures affect SMR and body condition}

In amphibian larvae as in all ectothermic animals, ambient temperature regulates the rates of all physiological and biochemical processes (Smith-Gill and Berven 1979; Tata 2006; Little and Seebacher 2016) impacting growth, development, and metabolism. An increase in ambient temperature may, therefore, substantially increase the SMR, but larvae may compensate for those thermal changes through acclimation and, thus, reduce the increase of SMR due to higher temperatures (Angilletta et al. 2006; Seebacher et al. 2015; Berg et al. 2017). Values for SMR were in the range of other studies and species (e.g., Lithobates sylvatica, Orlofske and Hopkins 2009; Xenopus laevis, Ruthsatz et al. 2018c; Rana temporaria, Lindgren and Laurila 2009; Rana pipiens; Steyermark et al. 2005). In this study, the SMR of larval $R$. temporaria was higher when larvae developed at higher temperatures. Moreover, SMR was relatively stable in all hormone treatments across temperatures treatments from 14 to $22{ }^{\circ} \mathrm{C}$. Not until $25{ }^{\circ} \mathrm{C}$, SMR increased significantly compared to other temperature treatments independent from TH level. As the variability in SMR increased at higher temperatures, we suggest that larvae differed in their capacity for physiological plasticity at the individual level with some still maintaining a relatively stable SMR as shown for temperatures from 14 to $22{ }^{\circ} \mathrm{C}$ by acclimation to higher temperatures. Furthermore, our results indicate that the optimum temperature to maintain SMR during development is around 
$18{ }^{\circ} \mathrm{C}$ mostly independent from $\mathrm{TH}$ levels. Thus, environmental stress may not influence the optimum temperature for maintaining a constant SMR. In natural breeding ponds of $R$. temporaria, temperatures during development are within this optimum temperature range and may outstrip this range under short-term temperature fluctuations (i.e., diurnal change) and in late developmental stages due to a seasonal mean temperature increase. However, Drakulić et al. (2017) demonstrated that mean seasonal temperature in Germany and southern Europe was $20^{\circ} \mathrm{C}$ and lower suggesting that larvae of $R$. temporaria may experience mean temperatures within their thermal optimum for maintaining a stable SMR under natural conditions.

Climate change is altering patterns of environmental temperature with potentially important repercussions for ectotherms that must simultaneously cope with contaminants or other environmental stressors (Hallman and Brooks 2015). In this study, SMR was increased also at low TH levels through the exposure to SP, and we suggest that aquatic contaminants alone may result in increased metabolism due their toxicity independent from the thyroid metabolism. Chronically higher metabolism, from contaminants alone, occurs in fish (Beyers et al. 1999), larval amphibians (McDaniel et al. 2004), and bivalves (Lannig et al. 2008; reviewed in Hallman and Brooks 2015). Thus, researchers are raising concern that organisms living in chronically polluted water might be at greater risk from global warming if they cannot provide the additional energy needed to cope with simultaneous thermal stress (Rowe and Crandall 2018). Therefore, it has also been suggested that not climate change itself may affect amphibians, but rather will act in combination with biotic and abiotic factors increasing their effects (López-Alcaide and Macip-Ríos 2011; Baier et al. 2016). In the present study, the effect of high TH level was not intensified at higher temperatures. Therefore, larvae exposed to higher temperatures are not likely to be affected more by environmental stressors than larvae at colder temperatures experienced before and during metamorphic climax.

In general, ectothermic species from temperate latitudes display a greater capacity for physiological acclimation than species from tropical climates (reviewed in Vo and Gridi-Papp 2017). Therefore, a capacity to respond plastically in physiological traits should be high in temperate species such as R. temporaria (Janzen 1967). In particular, larvae of $R$. temporaria are known to have a more plastic response to environmental variation than other species (Laurila and Kujasalo 1999; Groezinger et al., 2018). This is especially true in terms of growth and developmental rate as they are exposed to large inter- and intra-annual habitat variability. Therefore, temperate anuran species in general but especially larvae of $R$. temporaria may compensate for direct (i.e., temperature increase) and indirect effects (i.e., shortening of hydroperiod, increasing tadpole density, and the concentration of contaminants as the pond desiccates; Egea-Serrano and Van Buskirk 2016) of global warming through temperature-induced developmental and physiological plasticity. Thus, those species may be less vulnerable to the thermal impacts of climate change than tropical species. However, a higher SMR may also be adaptive in the face of global change, since a higher SMR is likely to allow for quicker metamorphosis in larval amphibians and, thus, for passing this highly vulnerable phase. Furthermore, a higher SMR in larvae can be associated with adaptable traits, like increased activity, or competitive ability (i.e., foraging efficiency and space occupancy). With a fast foraging rate, one would expect body size to increase faster than slower foragers. Also, a higher SMR in juvenile and adult amphibians is also related to higher activity and forgaing success and better dispersal. If so, a high SMR may even be selected for under natural circumstances. However, the capacity for temperature-induced plasticity is known to be related to local adaptations in anuran larvae (Laugen et al. 2003; Muir et al. 2014; Drakulić et al. 2016) and, thus, is population-specific.

Despite temperature effects on SMR, reductions in body condition (i.e., the ability to store energy) were noted in larvae having altered levels of THs that were reared at higher temperatures (i.e. the interactive effect of multiple stressors). Since (anthropogenic) global change will introduce multiple environmental stressors (e.g., changes in temperature and additional factors) to natural larval habitats of anuran larvae, the capacity to store energy during the larval stage may be reduced with possible ramifications for the energetic efficiency of metamorphosis. Independent from $\mathrm{TH}$ status, body condition was highest and SMR was relatively low in larvae reared at 14,18 , and $22{ }^{\circ} \mathrm{C}$, and SMR was also relatively low at these temperatures, and therefore, our results underscore that the optimum temperature during development is between 18 and $22{ }^{\circ} \mathrm{C}$. This is in accordance with the previous studies (Rühmekopf 1958; Drakulić et al., 2017). Any increase in temperatures above this optimum increases SMR and may lead to a small but constant increase in energetic demands. Potential consequences of increased metabolic expenditures in a resource-limited, high density system are reduced growth, developmental rates, or larval survival, which could ultimately affect recruitment to the terrestrial habitat (Rowe and Crandall 2018; Ruthsatz et al. 2018b). In contrast to TH level and temperature effects on SMR, effects on body condition were distinct. Therefore, we assume that higher $T_{\mathrm{dev}}$ and altered TH levels affect body condition independently from effects on SMR. As we could recently show that TH level significantly affects energy allocation to 
developmental and maintenance cost during metamorphic climax (Ruthsatz et al. 2019), we suppose that energy allocation might be disrupted by altered TH level and higher $T_{\mathrm{dev}}$ at all life stages.

\section{Carry-over effects on post-metamorphic stage}

Sublethal stressful conditions experienced during larval stage can have long-term consequences for performance and fitness through carry-over effects (Räsänen et al. 2002; Crean et al. 2011). In the present study, we clearly demonstrated that larval exposure to higher developmental temperatures and environmental stress not only affects SMR and body condition at the onset of metamorphosis but also at the end of metamorphic climax in froglets of $R$. temporaria. Consequently, we follow Pechenik (2006) in suggesting that metamorphosis is not "a new beginning", since effects of stressful larval environments may persist beyond the metamorphic boundary and result in strong carry-over effects on juveniles and adults (Smith 1987; Berven 1990; Goater 1994; Pechenik 2006; Altwegg and Reyer 2003; Scott et al. 2007; Morey and Reznick 2001; Van Allen et al. 2010). A very few studies have investigated the mechanistic underpinnings of altered physiological machanisms (i.e., SMR and energy stores) associated with altered $\mathrm{TH}$ levels as caused by environmental stressors and developmental temperature. Since THs are the major triggers of energy metabolism and are positively correlated with metabolic rate (McNabb and King 1993; Rowe et al. 1998; Burraco and Gomez-Mestre 2016) including maintenance costs (Orlofske and Hopkins 2009; Ruthsatz et al. 2019), larvae experiencing environmental stress may show a different capacity to store energy, which in turn impacts their body condition at the onset of metamorphosis, energy budget for metamorphic climax, and body condition after completion of metamorphosis. In a previous study, we showed that TH level affects energy allocation and energetic efficiency of metamorphic climax (Ruthsatz et al. 2019). We assume that this effect is more pronounced at higher developmental temperatures leading to the profound reductions in body condition at higher temperatures in the present study. Effects of TH level and developmental temperature on energy allocation seem to be more effective than those on SMR. However, other factors might also be involved such as larval density which directly influences developmental and growth rate (Semlitsch and Caldwell 1982; Wilbur 1977; Dash and Hota 1980) Yagi and Green (2016) found that in toad Anaryxus fowleri, a larval density of $1.67 / 1$ was stressful resulting in smaller larvae. Other studies, however, use higher densities than used in this study (Ding et al. 2015). Examining post-metamorphic fitness consequences of larval traits in isolation is likely to obscure important interactive effects (Crean et al. 2011). Therefore, we assume that carry-over effects on body condition of juvenile froglets are a result of a complex interaction between different physiological traits during metamorphosis. However, carry-over effects were measured at the end of metamorphosis, at 11 weeks maximum. Thus, carry-over effects during the proceeding juvenile stage are still unknown, and growth compensation may be an important component of developmental plasticity not studied here. Furthermore, carry-over effects are evident at 11 weeks, but it is unclear how lasting these effects may be. Nevertheless, Morey and Reznick (2001) state that carry-over effects from larval to juvenile stage are suggested to remain for at least several months after metamorphosis. Consequently, in temperate $R$. temporaria, carry-over effects on body condition may impair the capacity for energy accumulation needed for a successful hibernation in winter and, thus, juvenile survival.

\section{Thermal tolerance is determined by developmental temperature}

Understanding the capacity for plasticity in the range of thermal tolerance and how this plasticity is altered by other environmental stressors may be crucial to predicting how physiological variation can influence a species' response to global change (Katzenberger et al. 2014; Seebacher et al. 2015). In this study, larvae exhibited thermal acclimation, such that individuals from higher developmental temperatures increased their $\mathrm{CT}_{\max }$ and broadened their range in tolerable temperatures, mechanisms previously observed in other amphibians (Schaefer and Ryan 2006; Gunderson and Stillman 2015; Little and Seebacher 2016). We could not report any significant effects of altered TH levels on the upper thermal limit and the thermal range of tolerance in $R$. temporaria, indicating that these physiological traits are not under the control of the thyroid system. Therefore, altered TH levels as caused by environmental stressors may not affect the capacity for an acclimation in upper thermal limits and thermal range of tolerance. Thus, larvae under environmental stress are still able to compensate for changes in developmental temperature.

Even if a long-term increase in annual average temperature is the consequence of global climate change, environmental change also results in short-term, both stochastic and predictable, extreme thermal events, particularly in temperate freshwater habitats (Seebacher et al. 2015; Gutiérrez-Pesquera et al. 2016; Burggren 2018). Therefore, laboratory studies on the capacity for physiological plasticity in thermal tolerance (especially in $\mathrm{CT}_{\max }$ ) as the present study are of special relevance for predictions on 
vulnerability of anuran larvae to those short-term thermal challenges. Current IPCC models for global temperature in the coming century (IPCC 2014) do not suggest warming of the magnitude necessary to threaten temperate larvae such as $R$. temporaria by exceeding their $\mathrm{CT}_{\max }$ (Rowe and Crandall 2018). In contrast, positive effects of climate-driven warming are expected in populations of many organisms that occur at temperatures colder than their thermal optima (Deutsch et al. 2008; Kingsolver et al. 2013; reviewed in Egea-Serrano and Van Buskirk 2016). This appears to be the case for $R$. temporaria in central and northern Europe (Duarte et al. 2012) but may not for populations in southern Europe as they are locally adapted to higher temperatures (Lindgren and Laurila 2009). However, climatic anomalies as recorded in Europe for summer temperatures in 2003 (Neveu 2009) and recent spring and summer in 2018 and 2019 (Deutscher Wetterdienst 2008) representing the highest seasonal temperatures, since weather was recorded (Luterbacher et al. 2004; Neveu 2009; Deutscher Wetterdienst), may lead to sub-optimal temperatures accompanied by an increased desiccation risk and decreased food availability in larval habitats of $R$. temporaria. So far, it is challenging to project winners and losers in terms of climate change in light of the fact that multiple factors, beyond mere warming or increased variance in temperature, may simultaneously occur.

\section{Conclusions}

Environmental change due to global warming and other environmental stressors is complex and often unpredictable (Burggren 2018) and anuran larvae will, therefore, be exposed to multiple environmental stressors. Our study combines the effects of the multiple stressors accompanying direct effects of climate change in a multifactorial design. By directly altering the TH levels, we simulate the proximate effects of various environmental stressors and may conclude how proximate effects of multiple stressors may affect the acclimation capacity of amphibians across life stages. Our results emphasize that of $R$. temporaria might cope with short- and long-term changes as larvae and froglets are able to compensate to some extent for new thermal challenges independent from interactions with other environmental stressors impairing growth and development by altering endogenous TH levels. Thus, higher temperatures during development could result in increased mean fitness in temperate species such as $R$. temporaria compared to tropical species. As environmental temperatures greatly influence the behavior and physiology but also the distribution of aquatic ectotherms (Narum et al.
2013), the capacity for acclimation to higher temperatures may influence the frog range expansion into hotter climates (Seebacher and Franklin 2011; Jessop et al. 2018). However, $R$. temporaria is distributed over a wide geographic range with large differences in climatic conditions (Stahlberg et al. 200; Lindgren and Laurila 2009), and thus, populations may differ in their local adaptations to thermal environments and their acclimation capacity. Comparative studies across populations and species would help to identify the potential for acclimation or inter-specific differences, respectively. The present findings also emphasize that impacts of larval environment on physiological traits (i.e., SMR and body condition) at the onset of metamorphosis persist beyond metamorphic climax to postmetamoprhic stage by carry-over effects. As phenotypic traits are often used as indicators of the effects of the larval stage on future fitness for organisms with complex life cycles, we suggest that multiple environmental stressors associated with global change may affect all life stages of amphibians with possible consequences for individual fitness and longlasting effects on amphibian populations. More research needs to be conducted to elucidate how the levels of stress and the interactions of stressors in both the larval and the later juvenile stages affect what is carried from the larval to juvenile life-history stages in organisms with complex life cycles (Van Allen et al. 2010). Future studies on physiological plasticity of larval anurans should investigate whether the ability for acclimation changes across life stages and should focus on long-term carry-over effects on juvenile and adult performance.

Acknowledgements Open Access funding provided by Projekt DEAL. The authors would like to thank J. Bank for his experimental advice and technical assistance.

Author contributions KR, KHD, MP, and JG conceived and designed the study; KR, TR, and SR performed experiments; KR analyzed the data; KR, KHD, and JG interpreted results of experiments; KR and NS prepared the figures and drafted the manuscript; all authors edited and revised the manuscript; all authors approved the final version of the manuscript.

Funding This research did not receive any specific grant from funding agencies in the public, commercial, or not-for-profit sectors. K. Ruthsatz was employed as a doctorate research associate at the University of Hamburg during these experiments.

\section{Compliance with ethical standards}

Conflict of interest The authors declare that they have no competing interests.

Ethical statement The authors have no ethical conflicts to disclose. The experiments were conducted under permission from the Amt für Verbraucherschutz, Lebensmittelsicherheit, und Veterinärwesen in Ham- 
burg, Germany (Billstraße 80, D- 20539 Hamburg; Gz. V1305/59100.33 , Nr. 03/16). The permission for extraction of spawn of the Common frog (Rana temporaria) was granted by the Amt für Naturschutz, Grünplanung und Energie (Neuenfelder Straße 19, D- 21109 Hamburg; Gz. NGE3102/897.20-90).

Open Access This article is licensed under a Creative Commons Attribution 4.0 International License, which permits use, sharing, adaptation, distribution and reproduction in any medium or format, as long as you give appropriate credit to the original author(s) and the source, provide a link to the Creative Commons licence, and indicate if changes were made. The images or other third party material in this article are included in the article's Creative Commons licence, unless indicated otherwise in a credit line to the material. If material is not included in the article's Creative Commons licence and your intended use is not permitted by statutory regulation or exceeds the permitted use, you will need to obtain permission directly from the copyright holder. To view a copy of this licence, visit http://creativecommons.org/licenses/by/4.0/.

\section{Appendix}

See Tables 4 and 5.
Table 4 Descriptive statistics of mass (mg) at the onset of metamorphosis (Gosner stage 42) and after completion of metamorphic climax (Gosner stage 46) in larvae and froglets of the common frog $R$. temporaria at five different developmental temperatures exposed at different TH levels

\begin{tabular}{|c|c|c|c|c|c|c|}
\hline Temperature & Treatment & Maximum & Minimum & Mean & SE & $N$ \\
\hline \multicolumn{7}{|c|}{ Mass (mg) at the onset of metamorphosis (Gosner stage 42) } \\
\hline \multirow[t]{3}{*}{14} & Control & 578 & 640 & 605.9 & 2.2 & 41 \\
\hline & Low TH & 632 & 702 & 671.3 & 2.9 & 43 \\
\hline & High TH & 380 & 419 & 400.2 & 1.7 & 39 \\
\hline \multirow[t]{3}{*}{18} & Control & 471 & 500 & 484.2 & 1.2 & 43 \\
\hline & Low TH & 499 & 549 & 521.2 & 2.23 & 41 \\
\hline & High TH & 296 & 335 & 312.4 & 1.9 & 42 \\
\hline \multirow[t]{3}{*}{22} & Control & 346 & 384 & 362.0 & 1.5 & 55 \\
\hline & Low TH & 433 & 496 & 462.4 & 2.5 & 59 \\
\hline & High TH & 172 & 206 & 188.7 & 1.6 & 49 \\
\hline \multirow[t]{3}{*}{25} & Control & 112 & 152 & 133.3 & 1.7 & 38 \\
\hline & Low TH & 219 & 254 & 233.3 & 1.8 & 35 \\
\hline & High TH & 83 & 104 & 94.7 & 1.1 & 31 \\
\hline \multirow[t]{3}{*}{28} & Control & 62 & 99 & 81.1 & 1.4 & 41 \\
\hline & Low TH & 96 & 134 & 113.1 & 1.8 & 42 \\
\hline & High TH & 51 & 89 & 69.6 & 2.1 & 28 \\
\hline \multicolumn{7}{|c|}{ Mass (mg) after completion of metamorphosis (Gosner stage 46) } \\
\hline \multirow[t]{3}{*}{14} & Control & 379 & 417 & 401.1 & 1.4 & 41 \\
\hline & Low TH & 412 & 469 & 435.5 & 2.6 & 39 \\
\hline & High TH & 217 & 248 & 228.5 & 1.5 & 34 \\
\hline \multirow[t]{3}{*}{18} & Control & 284 & 315 & 302.8 & 1.5 & 42 \\
\hline & Low TH & 349 & 405 & 373.3 & 2.8 & 36 \\
\hline & High TH & 80 & 113 & 94.5 & 1.4 & 37 \\
\hline \multirow[t]{3}{*}{22} & Control & 93 & 124 & 105.2 & 1.3 & 53 \\
\hline & Low TH & 274 & 314 & 293.6 & 1.4 & 55 \\
\hline & High TH & 42 & 67 & 52.2 & 1.2 & 42 \\
\hline \multirow[t]{3}{*}{25} & Control & 42 & 65 & 50.8 & 1.3 & 33 \\
\hline & Low TH & 59 & 96 & 75.0 & 2.3 & 34 \\
\hline & High TH & 37 & 54 & 46.1 & 1.0 & 27 \\
\hline \multirow[t]{3}{*}{28} & Control & 34 & 49 & 41.3 & 0.7 & 36 \\
\hline & Low TH & 40 & 58 & 49.0 & 0.9 & 38 \\
\hline & High TH & 29 & 42 & 36.4 & 0.8 & 23 \\
\hline
\end{tabular}

T4 high TH level, SP low TH level 
Table 5 Critical thermal minima $\left(\mathrm{CT}_{\min }\right)$, critical thermal maxima $\left(\mathrm{CT}_{\max }\right)$, and the thermal range of tolerance (TRT) of larvae of the common frog Rana temporaria at five different developmental temperatures exposed at different TH levels caused by environmental stress

\begin{tabular}{|c|c|c|c|c|c|c|}
\hline $\begin{array}{l}\text { Developmental } \\
\text { temperature }\left({ }^{\circ} \mathrm{C}\right)\end{array}$ & Treatment & $\mathrm{CT}_{\min }\left({ }^{\circ} \mathrm{C}\right) \pm \mathrm{SD}$ & $\mathrm{CT}_{\max }\left({ }^{\circ} \mathrm{C}\right) \pm \mathrm{SD}$ & $\mathrm{TRT} \pm \mathrm{SD}$ & Regression slope $\mathrm{CT}_{\min }\left(R^{2}\right)$ & Regression slope $\mathrm{CT}_{\max }\left(R^{2}\right)$ \\
\hline 14 & \multirow[t]{5}{*}{ Control } & $\mathbf{4 . 2 2} \pm 0.19$ & $\mathbf{3 2 . 0 8} \pm 0.12$ & $\mathbf{2 7 . 8 6} \pm 0.17$ & \multirow[t]{5}{*}{$y=1.013+0.223 x(0.969)$} & \multirow[t]{5}{*}{$y=24.145+0.577 x(0.394)$} \\
\hline 18 & & $\mathbf{5 . 0 9} \pm 0.10$ & $\mathbf{3 4 . 3 4} \pm 0.18$ & $\mathbf{2 9 . 2 4} \pm 0.22$ & & \\
\hline 22 & & $\mathbf{5 . 6 1} \pm 0.18$ & $\mathbf{3 6 . 6 3} \pm 0.92$ & $\mathbf{3 1 . 0 2} \pm 0.04$ & & \\
\hline 25 & & $6.86 \pm 0.14$ & $\mathbf{4 0 . 3 1} \pm 0.19$ & $\mathbf{3 3 . 4 4} \pm 0.25$ & & \\
\hline 28 & & $7.29 \pm 0.23$ & $39.13 \pm 0.14$ & $\mathbf{3 1 . 8 4} \pm 0.21$ & & \\
\hline 14 & \multirow[t]{5}{*}{ Low TH } & $\mathbf{4 . 6 6} \pm 0.13$ & $\mathbf{3 3 . 0 5} \pm 0.12$ & $28.39 \pm 0.16$ & \multirow[t]{5}{*}{$y=0.899+0.242 x(0.928)$} & \multirow[t]{5}{*}{$y=25.236+0.579 x(0.895)$} \\
\hline 18 & & $\mathbf{5 . 5 3} \pm 0.15$ & $\mathbf{3 5 . 0 4} \pm 0.11$ & $29.5 \pm 0.17$ & & \\
\hline 22 & & $\mathbf{5 . 9 1} \pm 0.13$ & $39.17 \pm 0.15$ & $\mathbf{3 3 . 2 6} \pm 0.25$ & & \\
\hline 25 & & $7.23 \pm 0.22$ & $\mathbf{4 0 . 7 3} \pm 0.16$ & $\mathbf{3 3 . 5} \pm 0.3$ & & \\
\hline 28 & & $7.63 \pm 0.23$ & $\mathbf{4 0 . 1 4} \pm 0.18$ & $\mathbf{3 2 . 5 1} \pm 0.25$ & & \\
\hline 14 & \multirow[t]{5}{*}{ High TH } & $\mathbf{4 . 0 4} \pm 0.12$ & $\mathbf{3 1 . 7 3} \pm 0.27$ & $\mathbf{2 7 . 6 8} \pm 0.33$ & \multirow[t]{5}{*}{$y=0.955+0.209 x(0.801)$} & \multirow[t]{5}{*}{$y=22.799+0.637 x(0.738)$} \\
\hline 18 & & $\mathbf{4 . 5 9} \pm 0.19$ & $\mathbf{3 2 . 8 1} \pm 0.19$ & $\mathbf{2 8 . 2 1} \pm 0.31$ & & \\
\hline 22 & & $\mathbf{4 . 8 2} \pm 0.17$ & $\mathbf{3 8 . 3 3} \pm 0.20$ & $\mathbf{3 3 . 5 1} \pm 0.26$ & & \\
\hline 25 & & $6.45 \pm 0.12$ & $\mathbf{4 0 . 4 9} \pm 2.61$ & $\mathbf{3 4 . 0 4} \pm 2.63$ & & \\
\hline 28 & & $6.81 \pm 21$ & $38.79 \pm 0.16$ & $\mathbf{3 1 . 9 8} \pm 0.17$ & & \\
\hline
\end{tabular}

Regression slopes show the increase of $\mathrm{CT}_{\min }$ and $\mathrm{CT}_{\max }$ for every $1{ }^{\circ} \mathrm{C}$ increase in $T_{\mathrm{dev}}$. Bold for mean values

T4 high TH level, SP low TH level

\section{References}

Altwegg R, Reyer HU (2003) Patterns of natural selection on size at metamorphosis in water frogs. Evolution 57:872-882. https:// doi.org/10.1111/j.0014-3820.2003.tb00298.x

Angilletta MJ (2009) Looking for answers to questions about heat stress: researchers are getting warmer. Funct Ecol 23:231-232. https://doi.org/10.1111/j.1365-2435.2009.01548.x

Angilletta MJ, Niewiarowski PH, Navas CA (2002) The evolution of thermal physiology in ectotherms. J Therm Biol 27:249-268. https://doi.org/10.1016/S0306-4565(01)00094-8

Angilletta MJ, Bennett AF, Guderley H, Navas CA, Seebacher F, Wilson RS (2006) Coadaptation: a unifying principle in evolutionary thermal biology. Physiol Biochem Zool 79:282-294. https://doi. org/10.1086/499990

Angilletta MJ, Cooper BS, Schuler MS, Boyles JG (2010) The evolution of thermal physiology in endotherms. Front Biosci E 2:861-881

Baier F, Jedinger M, Gruber E, Zaller JG (2016) Temperature-dependence of glyphosate-based herbicide's effects on egg and tadpole growth of common toads. Front Environ Sci 4:51. https://doi. org/10.3389/fenvs.2016.00051

Bates DM, Sarkar D (2007) 1me 4: linear mixed-effects models using s4 classes (version 0.999375-39) [Computer software and manual]

Beck CW, Congdon JD (2000) Effects of age and size at metamorphosis on performance and metabolic rates of Southern Toad, Bufo terrestris, metamorphs. Funct Ecol 14:32-38. https://doi.org/10 .1046/j.1365-2435.2000.00386.x

Beck CW, Congdon JD (2003) Energetics of metamorphic climax in the southern toad (Bufo terrestris). Oecologia 137:344-351. https://doi.org/10.1007/s00442-003-1374-5

Berg W, Theisinger O, Dausmann KH (2017) Acclimatization patterns in tropical reptiles: uncoupling temperature and energetics. Sci Nat 104:91. https://doi.org/10.1007/s0011 4-017-1506-0

Berven KA (1990) Factors affecting population fluctuations in larval and adult stages of the wood frog (Rana sylvatica). Ecology 71:1599-1608. https://doi.org/10.2307/1938295

Berven KA, Gill DE (1983) Interpreting geographic variation in life-history traits. Am Zool 23:85-97. https://doi.org/10.1093/ icb/23.1.85

Bethge J, Wist B, Stalenberg E, Dausmann K (2017) Seasonal adaptations in energy budgeting in the primate Lepilemur leucopus. J Comp Physiol B 187:827-834. https://doi.org/10.1007/s0036 0-017-1082-9

Beyers DW, Rice JA, Clements WH (1999) Evaluating biological significance of chemical exposure to fish using a bioenergeticsbased stressor-response model. Can J Fish Aquat Sci 56:823829. https://doi.org/10.1139/F10-082

Blaustein AR, Han BA, Relyea RA, Johnson PT, Buck JC, Gervasi SS, Kats LB (2011) The complexity of amphibian population declines: understanding the role of cofactors in driving amphibian losses. Ann N Y Acad Sci 1223:108-119. https://doi.org/10 $.1111 /$ j.1749-6632.2010.05909.x

Bolker BM, Brooks ME, Clark CJ, Geange SW, Poulsen JR, Stevens MHH, White JSS (2009) Trends Ecol Evol 24:127-135. https:// doi.org/10.1016/j.tree.2008.10.008

Boone MD, Semlitsch RD, Little EE, Doyle MC (2007) Multiple stressors in amphibian communities: effects of chemical contamination, bullfrogs, and fish. Ecol Appl 17:291-301. https:// doi.org/10.1890/1051-0761(2007)017[0291:MSIACE]2.0.CO;2

Brown DD, Cai L (2007) Amphibian metamorphosis. Dev Biol 306:20

Browne RK, Pomering M, Hamer AJ (2003) High density effects on the growth, development and survival of Litoria aurea larvae. Aquaculture 215:109-121. https://doi.org/10.1016/S0044 -8486(02)00205-3

Bulaeva E, Lanctôt C, Reynolds L, Trudeau VL, Navarro-Martín L (2015) Sodium Perchlorate disrupts development and affects 
metamorphosis-and growth-related gene expression in larvae of the wood frog (Lithobates sylvaticus). Gen Comp Endocrinol 22:33-43. https://doi.org/10.1016/j.ygcen.2015.01.012

Bullock TH (1955) Compensation for temperature in the metabolism and activity of poikilotherms. Biol Rev 30:311-342. https:// doi.org/10.1111/j.1469-185X.1955.tb01211.x

Burggren W (2018) Developmental phenotypic plasticity helps bridge stochastic weather events associated with climate change. J Exp Biol 22:jeb161984. https://doi.org/10.1242/ jeb.161984

Capellán E, Nicieza AG (2007) Trade-offs across life stages: does predator-induced hatching plasticity reduce anuran post-metamorphic performance? Evol Ecol 21:445-458. https://doi. org/10.1007/s10682-006-9133-9

Carr JA, Patiño R (2011) The hypothalamus-pituitary-thyroid axis in teleosts and amphibians: endocrine disruption and its consequences to natural populations. Gen Comp Endocrinol 170:299312. https://doi.org/10.1016/j.ygcen.2010.06.001

Carr JA, Theodorakis CW (2006) Perchlorate effects in amphibians. The ecotoxicology of perchlorate. SETAC Press, Pensacola, pp $127-154$

Chelgren ND, Rosenberg DK, Heppell SS, Gitelman AJ (2006) Carryover aquatic effects on survival of metamorphic frogs during pond emigration. Ecol Appl 16:250-261. https://doi. org/10.1890/04-0329

Choi J, Ishizuya-Oka A, Buchholz DR (2017) Growth, development, and intestinal remodeling occurs in the absence of thyroid hormone receptor $\alpha$ in larvae of Xenopus tropicalis. Endocrinology 158:1623-1633. https://doi.org/10.1210/en.2016-1955

Coady K, Marino T, Thomas J, Currie R, Hancock G, Crofoot J, Klecka $\mathrm{G}$ et al (2010) Evaluation of the amphibian metamorphosis assay: Exposure to the goitrogen Methimazole and the endogenous thyroid hormone L-thyroxine. Environ Toxicol Chem 29:869-880. https://doi.org/10.1002/etc.74

Cowles RB, Bogert CM (1944) A preliminary study of the thermal requirements of desert reptiles. Bull AMNH 83:261-296 (article 5)

Crawley MJ (2007) The R book. Wiley, Chichester

Crean AJ, Monro K, Marshall DJ (2011) Fitness consequences of larval traits persist across the metamorphic boundary. Evolut Int J Org 65(3079):3089. https://doi.org/10.1111/j.1558-5646.2011.01372 . $\mathrm{x}$

Dalvi RS, Pal AK, Tiwari LR, Das T, Baruah K (2009) Thermal tolerance and oxygen consumption rates of the catfish Horabagrus brachysoma (Günther) acclimated to different temperatures. Aquaculture 295:116-119. https://doi.org/10.1016/j.aquacultur e.2009.06.034

Dantzer B, Fletcher QE, Boonstra R, Sheriff MJ (2014) Measures of physiological stress: a transparent or opaque window into the status, management and conservation of species? Conserv Physiol. https://doi.org/10.1093/conphys/cou023

Dash MC, Hota AK (1980) Density effects on the survival, growth rate, and metamorphosis of Rana tigrina larvae. Ecology 61:10251028. https://doi.org/10.2307/1936818

Denver RJ (1997) Environmental stress as a developmental cue: corticotropin-releasing hormone is a proximate mediator of adaptive phenotypic plasticity in amphibian metamorphosis. Horm Behav 31:169-179. https://doi.org/10.1006/hbeh.1997.1383

Denver RJ (1998) Hormonal correlates of environmentally induced metamorphosis in the Western spadefoot toad, Scaphiopus hammondii. Gen Comp Endocrinol 110:326-336. https://doi. org/10.1006/gcen.1998.7082

Denver RJ (2009) Stress hormones mediate environment-genotype interactions during amphibian development. Gen Comp Endocrinol 164:20-31. https://doi.org/10.1016/j.ygcen.2009.04.016
Denver RJ, Glennemeier KA, Boorse GC (2002) Endocrinology of complex life cycles: amphibians. Horm Brain Behav. https://doi. org/10.1016/B978-012532104-4/50030-5

Deutscher Wetterdienst (2018) https://www.dwd.de/DE/wetter/thema _des_tages/2018/7/31.html Accessed 19 Sept 2018

Deutsch CA, Tewksbury JJ, Huey RB, Sheldon KS, Ghalambor CK, Haak DC, Martin PR (2008) Impacts of climate warming on terrestrial ectotherms across latitude. Proc Natl Acad Sci 105:6668-6672. https://doi.org/10.1073/pnas.0709472105

Deutsch C, Ferrel A, Seibel B, Pörtner HO, Huey RB (2015) Climate change tightens a metabolic constraint on marine habitats. Science 348:1132-1135. https://doi.org/10.1126/science.aaa1605

Ding GH, Lin ZH, Fan XL, Ji X (2015) The combined effects of food supply and larval density on survival, growth and metamorphosis of Chinese tiger frog (Hoplobatrachus rugulosa) larvae. Aquaculture 435:398-402. https://doi.org/10.1016/j. aquaculture.2014.10.025

Dittrich C, Drakulić S, Schellenberg M, Thein J, Rödel MO (2016) Some like it hot? Developmental differences in Yellow-bellied Toad (Bombina variegata) larvae from geographically close but different habitats. Can J Zool 94:69-77

Drakulić S, Feldhaar H, Lisičić D, Mioč M, Cizelj I, Seiler M, Rödel MO et al (2016) Population-specific effects of developmental temperature on body condition and jumping performance of a widespread European frog. Ecol Evol 6:3115-3128. https://doi. org/10.1002/ece 3.2113

Drakulić S, Feldhaar H, Lisičić D, Mioč M, Cizelj I, Seiler M, Rödel MO et al (2017) Local differences of thermal preferences in European common frog (Rana temporaria Linnaeus, 1758) larvae. J Comp Zool 268:47-54. https://doi.org/10.1016/j. jcz.2017.04.005

Duarte H, Tejedo M, Katzenberger M, Marangoni F, Baldo D, BeltránGonzalez-Voyer JFA et al (2012) Can amphibians take the heat? Vulnerability to climate warming in subtropical and temperate larval amphibian communities. Glob Change Biol 18:412-421. https://doi.org/10.1111/j.1365-2486.2011.02518 .x

Egea-Serrano A, Van Buskirk J (2016) Responses to nitrate pollution, warming and density in common frog larvae (Rana temporaria). Amphibia Reptilia 37:45-54. https://doi. org/10.1163/15685381-00003029

Etheridge K (1993) Thyroxine-induced changes in metabolic rate and cytochrome oxidase activity in Thamnophis sirtalis: effects of nutritional status. Gen Comp Endocrinol 91:66-73. https://doi. org/10.1006/gcen.1993.1105

Feder ME (1982) Environmental variability and thermal acclimation of metabolism in tropical anurans. J Therm Biol 7:23-28. https ://doi.org/10.1016/0306-4565(82)90015-8

Ficetola GF, De Bernardi F (2006) Trade-off between larval development rate and post-metamorphic traits in the frog Rana latastei. Evol Ecol 20:143-158. https://doi.org/10.1007/s1068 2-005-5508-6

Formicki G, Zamachowski W, Stawarz R (2003) Effects of UV-A and UV-B on oxygen consumption in common toad (Bufo bufo) larvae. J Zool 259:317-326. https://doi.org/10.1017/S0952 836902003345

Furlow JD, Neff ES (2006) A developmental switch induced by thyroid hormone: Xenopus laevis metamorphosis. Trends Endocrinol Metab 17:40-47. https://doi.org/10.1016/j. tem.2006.01.007

Gervasi SS, Foufopoulos J (2008) Costs of plasticity: responses to desiccation decrease post-metamorphic immune function in a pond-breeding amphibian. Funct Ecol 22:100-108. https://doi. org/10.1111/j.1365-2435.2007.01340.x

Glennemeier KA, Denver RJ (2002) Small changes in whole-body corticosterone content affect larval Rana pipiens fitness components. 
Gen Comp Endocrinol 127:16-25. https://doi.org/10.1016/S0016 $-6480(02) 00015-1$

Goater CP (1994) Growth and survival of postmetamorphic toads: interactions among larval history, density, and parasitism. Ecology 75:2264-2274. https://doi.org/10.2307/1940882

Goater CP, Semlitsch RD, Bernasconi MV (1993) Effects of body size and parasite infection on the locomotory performance of juvenile toads, Bufo bufo. Oikos. https://doi.org/10.2307/35452 05

Goleman WL, Carr JA, Anderson TA (2002a) Environmentally relevant concentrations of ammonium perchlorate inhibit thyroid function and alter sex ratios in developing Xenopus laevis. Environ Toxicol Chem 21:590-597. https://doi.org/10.1002/etc.5620210318

Goleman WL, Urquidi LJ, Anderson TA, Smith EE, Kendall RJ, Carr JA (2002b) Environmentally relevant concentrations of ammonium perchlorate inhibit development and metamorphosis in Xenopus laevis. Environ Toxicol Chem 21:424-430. https://doi. org/10.1002/etc.5620210227

Gomez-Mestre I, Saccoccio VL, Iijima T, Collins EM, Rosenthal GG, Warkentin KM (2010) The shape of things to come: linking developmental plasticity to post-metamorphic morphology in anurans. J Evol Biol 23:1364-1373. https://doi.org/10.111 1/j.1420-9101.2010.02016.x

Gosner KL (1960) A simplified table for staging anuran embryos and larvae with notes on identification. Herpetologica 16:183-190

Groezinger F, Feldhaar H, Thein J, Roedel MO (2018) Testing the impact of environmental conditions and matriline on tadpole developmental traits in the European Common Frog, Rana temporaria, in the field. Salamandra 54:201-209

Gunderson AR, Stillman JH (2015) Plasticity in thermal tolerance has limited potential to buffer ectotherms from global warming. Proc R Soc B. https://doi.org/10.1098/rspb.2015.0401

Hallman TA, Brooks ML (2015) The deal with diel: temperature fluctuations, asymmetrical warming, and ubiquitous metals contaminants. Eviron Pollut 206:88-94. https://doi.org/10.1016/j.envpo 1.2015.06.005

Harkey GA, Semlitsch RD (1988) Effects of temperature on growth, development, and color polymorphism in the ornate chorus frog Pseudacris ornate. Copeia. https://doi.org/10.2307/1445724

Hasting D, Burggren W (1995) Developmental changes in oxygen consumption regulation in larvae of the South African clawed frog Xenopus laevis. J Exp Biol 198:2465-2475

Hazel JR, Prosser CL (1974) Molecular mechanisms of temperature compensation in poikilotherms. Physiol Rev 54:620-677. https ://doi.org/10.1152/physrev.1974.54.3.620

Holzman N, McManus JJ (1973) Effects of acclimation on metabolic rate and thermal tolerance in the carpenter frog, Rana vergatipes. Comp Biochem Physiol A Physiol 45:833-842. https://doi. org/10.1016/0300-9629(73)90086-8

Hourdry J, L'Hermite A, Ferrand R (1996) Changes in the digestive tract and feeding behavior of anuran amphibians during metamorphosis. Physiol Zool 69:219-251. https://doi.org/10.1086/ physzool.69.2.30164181

Huey RB, Berrigan D, Gilchrist GW, Herron JC (1999) Testing the adaptive significance of acclimation: a strong inference approach. Am Zool 39:323-336. https://doi.org/10.1093/icb/39.2.323

Hulbert AJ, Else PL (2004) Basal metabolic rate: history, composition, regulation, and usefulness. Physiol Biochem Zool 77:869-876. https://doi.org/10.1086/422768

Hutchison VH (1961) Critical thermal maxima in salamanders. Physiol Zool 34:92-125. https://doi.org/10.1086/physzool.34.2.30152 688

Iwamuro S, Sakakibara M, Terao M, Ozawa A, Kurobe C, Shigeura T, Kikuyama S (2003) Teratogenic and anti-metamorphic effects of bisphenol A on embryonic and larval Xenopus laevis. Gen
Comp Endocrinol 133:189-198. https://doi.org/10.1016/S0016 $-6480(03) 00188-6$

Janzen DH (1967) Why mountain passes are higher in the tropics. Am Nat 101:233-249. https://doi.org/10.1086/282487

Jessop TS, Lane M, Wilson RS, Narayan EJ (2018) Testing for shortand long-term thermal plasticity in corticosterone responses of an ectothermic vertebrate. Physiol Biochem Zool 91:967-975. https://doi.org/10.1086/698664

John-Alder HB (1983) Effects of thyroxine supplementation on metabolic rate and aerobic capacity in a lizard. Am J Physiol Regul Integr Comp Physiol 244:R659-R666. https://doi.org/10.1152/ ajpregu.1983.244.5.R659

John-Alder HB, Morin PJ (1990) Effects of larval density on jumping ability and stamina in newly metamorphosed Bufo woodhousii fowleri. Copeia 1990:856-860. https://doi.org/10.2307/1446453

Kashiwagi K, Furuno N, Kitamura S, Ohta S, SugiharaUtsumi KK, Kashiwagi K et al (2009) Disruption of thyroid hormone function by environmental pollutants. J Health Sci 55:147-160. https:// doi.org/10.1248/jhs.55.147

Katzenberger M, Hammond J, Duarte H, Tejedo M, Calabuig C, Relyea RA (2014) Swimming with predators and pesticides: how environmental stressors affect the thermal physiology of larvae. PLoS One 9:e98265. https://doi.org/10.1371/journal.pone.0098265

Kern P, Cramp RL, Franklin CE (2015) Physiological responses of ectotherms to daily temperature variation. J Exp Biol. https:// doi.org/10.1242/jeb.123166

Kingsolver JG, Huey RB (2008) Size, temperature, and fitness: three rules. Evol Ecol Res 10:251-268

Kingsolver JG, Diamond SE, Buckley LB (2013) Heat stress and the fitness consequences of climate change for terrestrial ectotherms. Funct Ecol 27:1415-1423. https://doi. org/10.1111/1365-2435.12145

Kingsolver JG, Higgins JK, Augustine KE (2015) Fluctuating temperatures and ectotherm growth: distinguishing non-linear and time-dependent effects. J Exp Biol 218:2218-2225. https://doi. org/10.1242/jeb.120733

Kulkarni SS, Buchholz DR (2012) Beyond synergy: corticosterone and thyroid hormone have numerous interaction effects on gene regulation in Xenopus tropicalis larvae. Endocrinology 153:53095324. https://doi.org/10.1210/en.2012-1432

Kupferberg SJ (1997) Bullfrog (Rana catesbeiana) invasion of a California river: The role of larval competition. Ecology 78:17361751. https://doi.org/10.1890/0012-9658(1997)078[1736:BRCIO A]2.0.CO;2

Lannig G, Cherkasov AS, Portner HO, Bock C, Sokolova IM (2008) Cadmium-dependent oxygen limitation affects temperature tolerance in eastern oysters (Crassostrea virginica Gmelin). Am J Physiol Regul Integra Comp Physiol 294:R1338-R1346. https ://doi.org/10.1152/ajpregu.00793.2007

Laudet V (2011) The origins and evolution of vertebrate metamorphosis. Curr Biol 21:R726-R737. https://doi.org/10.1016/j. cub.2011.07.030

Laugen AT, Laurila A, Räsänen K, Merilä J (2003) Latitudinal countergradient variation in the common frog (Rana temporaria) development rates-evidence for local adaptation. J Evol Biol 16:996-1005. https://doi.org/10.1046/j.1420-9101.2003.00560.x

Laurila A, Kujasalo J (1999) Habitat duration, predation risk and phenotypic plasticity in common frog (Rana temporaria) larvae. J Anim Ecol 68:1123-1132. https://doi.org/10.104 6/j.1365-2656.1999.00354.x

Layne JR Jr, Claussen DL (1982) Seasonal variation in the thermal acclimation of critical thermal maxima (CTMax) and minima (CTMin) in the salamander Eurycea bislineata. J Therm Biol 7:29-33. https://doi.org/10.1016/0306-4565(82)90016-X

Lillywhite HB (2016) Behavior and physiology: an ecological and evolutionary viewpoint on the energy and water relations of 
ectothermic amphibians and reptiles. In: de Andrade DV, Bevier CR, de Carvalho JE (eds) Amphibian and reptile adaptations to the environment: interplay between physiology and behavior. CRC Press, Boca Raton

Lindgren B, Laurila A (2005) Proximate causes of adaptive growth rates: growth efficiency variation among latitudinal populations of Rana temporaria. J Evol Biol 18:820-828. https://doi.org/ 10.1111/j.1420-9101.2004.00875.x

Lindgren B, Laurila A (2009) Physiological variation along a geographical gradient: is growth rate correlated with routine metabolic rate in Rana temporaria larvae? Biol J Linn Soc 98:17-224. https://doi.org/10.1111/j.1095-8312.2009.01255.x

Little AG, Seebacher F (2014) Thyroid hormone regulates cardiac performance during cold acclimation in zebrafish (Danio rerio). J Exp Biol 217:718-725. https://doi.org/10.1242/ jeb.096602

Little AG, Seebacher F (2016) Acclimation, acclimatization, and seasonal variation in amphibians and reptiles. In: de Andrade DV, Bevier CR, de Carvalho JE (eds) Amphibian and reptile adaptations to the environment: interplay between physiology and behavior. CRC Press, Boca Raton

López-Alcaide S, Macip-Ríos R (2011) Effects of climate change in amphibians and reptiles. Biodiversity loss in a changing planet. InTech, London

Lucas EA, Reynolds WA (1967) Temperature selection by amphibian larvae. Physiol Zool 40:159-171. https://doi.org/10.1086/physz ool.40.2.30152451

Luterbacher J, Dietrich D, Xoplaki E, Grosjean M, Wanner H (2004) European seasonal and annual temperature variability, trends, and extremes since 1500. Science 303:1499-1503. https://doi. org/10.1126/science.1093877

Lutterschmidt WI, Hutchison VH (1997) The critical thermal maximum: data to support the onset of spasms as the definitive end point. Can J Zool 75:1553-1560. https://doi.org/10.1139/z97-782

Mann RM, Hyne RV, Choung CB, Wilson SP (2009) Amphibians and agricultural chemical review of the risks in a complex environment. Environ Pollut 157:2903-2927. https://doi.org/10.1016/j. envpol.2009.05.015

Martin TL, Huey RB (2008) Why "suboptimal" is optimal: Jensen's inequality and ectotherm thermal preferences. Am Nat 171:E102-E118. https://doi.org/10.1086/527502

McDaniel TV, Harris ML, Bishop CA, Struger J (2004) Development and survivorship of northern leopard frogs (Rana pipiens) and green frogs (Rana clamitans) exposed to contaminants in the water and sediments of the St. Lawrence River near Cornwall, Ontario. Water Qual Res J Can 39:160-174. https://doi. org/10.2166/wqrj.2004.025

Miwa S, Inui Y (1987) Effects of various doses of thyroxine and triiodothyronine on the metamorphosis of flounder (Paralichthys olivaceus). Gen Comp Endocrinol 67:356-363. https://doi. org/10.1016/0016-6480(87)90190-0

Miyata K, Ose K (2012) Thyroid hormone-disrupting effects and the amphibian metamorphosis assay. J Toxicol Pathol 25:1-9. https ://doi.org/10.1293/tox.25.1

Moran NA (1994) Adaptation and constraint in the complex life cycles of animals. Ann Rev Ecol Syst 25:573-600

Morey S, Reznick D (2001) Effects of larval density on postmetamorphic spadefoot toads (Spea hammondii). Ecology 82:510-522. https://doi.org/10.1890/0012-9658(2001)082[0510:EOLDO P] 2.0.CO;2

Motzer WE (2001) Perchlorate: problems, detection, and solutions. Environ Forensic 2:301-311

Muir AP, Biek R, Thomas R, Mable BK (2014) Local adaptation with high gene flow: temperature parameters drive adaptation to altitude in the common frog (Rana temporaria). Mol Ecol 23:561-574. https://doi.org/10.1111/mec.12624
Mukhi S, Patiño R (2007) Effects of prolonged exposure to perchlorate on thyroid and reproductive function in zebrafish. Toxicol Sci 96:246-254. https://doi.org/10.1093/toxsci/kfm001

Narayan EJ (2016) Assessing the physiological sensitivity of amphibians to extreme environmental change using the stress endocrine responses. In: de Andrade DV, Bevier CR, de Carvalho JE (eds) Amphibian and reptile adaptations to the environment: interplay between physiology and behavior. CRC Press, Boca Raton

Narum SR, Campbell NR, Meyer KA, Miller MR, Hardy RW (2013) Thermal adaptation and acclimation of ectotherms from differing aquatic climates. Mol Ecol 22:3090-3097. https://doi. org/10.1111/mec.12240

Navas CA, Gomes FR, De Domenico ES (2016) Physiological ecology and conservation of anuran amphibians. In: de Andrade DV, Bevier CR, de Carvalho JE (eds) Amphibian and reptile adaptations to the environment: interplay between physiology and behavior. CRC Press, Boca Raton

Neveu A (2009) Incidence of climate on common frog breeding: Longterm and short-term changes. Acta Oecol 35:671-678. https:// doi.org/10.1016/j.actao.2009.06.012

Nowakowski AJ, Watling JI, Thompson ME, Brusch GA IV, Catenazzi A, Whitfield SM, Todd BD et al (2018) Thermal biology mediates responses of amphibians and reptiles to habitat modification. Ecol Lett 21:345-355. https://doi.org/10.1111/ele.12901

Noyes PD, McElwee MK, Miller HD, Clark BW, van Tiem LA, Walcott KC, Erwin KN, Levin ED (2009) The toxicology of climate change: environmental contaminants in a warming world. Environ Int 35:971-986. https://doi.org/10.1016/j.envint.2009.02.006

Orlofske SA, Hopkins WA (2009) Energetics of metamorphic climax in the pickerl frog (Lithobates palustris). Comp Biochem Physiol A Mol Integr Physiol 154:191-196. https://doi.org/10.1016/j. cbpa.2009.06.001

Orlofske SA, Belden LK, Hopkins WA (2017) Effects of Echinostoma trivolvis metacercariae infection during development and metamorphosis of the wood frog (Lithobates sylvaticus). Comp Biochem Physiol A Mol Integr Physiol 203:40-48. https://doi. org/10.1016/j.cbpa.2016.08.002

Ortiz-Santaliestra ME, Sparling DW (2007) Alteration of larval development and metamorphosis by nitrate and perchlorate in southern leopard frogs (Rana sphenocephala). Arch Environ Contam Toxicol 53:639-646. https://doi.org/10.1007/s00244-006-0277-y

Oyamaguchi HM, Vo P, Grewal K, Do R, Erwin E, Jeong N, Tse K, Chen C, Miyake M, Lin A (2017) Thermal sensitivity of a Neotropical amphibian (Engystomops pustulosus) and its vulnerability to climate change. Biotropica. https://doi.org/10.1111/ btp. 12519

Paaijmans KP, Heinig RL, Seliga RA, Blanford JI, Blanford S, Murdock CC, Thomas MB (2013) Temperature variation makes ectotherms more sensitive to climate change. Glob Change Biol 19:2373-2380. https://doi.org/10.1111/gcb.12240

Pachauri RK, Allen MR, Barros VR, Broome J, Cramer W, Christ R, Church JA, Clarke L, Dahe Q, Dasgupta P (2014) Climate change 2014: synthesis report Contribution of Working Groups I, II and III to the fifth assessment report of the Intergovernmental Panel on Climate Change: IPCC. 10.013/epic.45156.d001

Pechenik JA (2006) Larval experience and latent effects-metamorphosis is not a new beginning. Integr Comp Biol 46:323-333. https://doi.org/10.1111/gcb.12240

Pechenik JA, Wendt DE, Jarrett JN (1998) Metamorphosis is not a new beginning. Bioscience 48:901-910. https://doi. org/10.2307/1313294

Peck MA, Moyano M (2016) Measuring respiration rates in marine fish larvae: challenges and advances. J Fish Biol 88:73-205. https:// doi.org/10.1111/jfb. 12810 
Polo-Cavia N, Gomez-Mestre I (2017) Pigmentation plasticity enhances crypsis in larval newts: associated metabolic cost and background choice behaviour. Sci Rep 7:39739. https://doi. org/10.1038/srep39739

Pörtner H (2001) Climate change and temperature-dependent biogeography: oxygen limitation of thermal tolerance in animals. Naturwissenschaften 88:137-146. https://doi.org/10.1007/s0011 40100216

Pörtner HO (2002) Climate variations and the physiological basis of temperature dependent biogeography: systemic to molecular hierarchy of thermal tolerance in animals. Comp Biochem Physiol A Mol Integr Physiol 132:739-761. https://doi. org/10.1016/S1095-6433(02)00045-4

Prosser CL (1955) Physiological variation in animals. Biol Rev 30:229-261

Räsänen K, Laurila A, Merilä J (2002) Carry-over effects of embryonic acid conditions on development and growth of Rana temporaria larvae. Freshw Biol 47:19-30. https://doi.org/10.104 6/j.1365-2427.2002.00777.x

Relyea RA (2002) Competitor-induced plasticity in larvae: consequences, cues, and connections to predator-induced plasticity. Ecol Monogr 72:523-540. https://doi.org/10.1890/00129615(2002)072[0523:CIPITC]2.0.CO;2

Rot-Nikcevic I, Wassersug RJ (2004) Arrested development in Xenopus laevis larvae: how size constrains metamorphosis. J Exp Biol 207:2133-2145. https://doi.org/10.1242/jeb.01002

Rowe CL, Crandall ES (2018) The acute thermal respiratory response is unique among species in a guild of larval anuran amphibians-implications for energy economy in a warmer future. Sci Total Environ 618:229-235. https://doi.org/10.1016/j.scito tenv.2017.10.332

Rowe CL, Funck SA (2017) Respiration rates of larval Cope's Gray Tree Frogs (Hyla chrysoscelis) across a range in temperatures. J Herpetol 51:130-133. https://doi.org/10.1670/16-029

Rowe CL, Kinney OM, Nagle RD, Congdon JD (1998) Elevated maintenance costs in an anuran (Rana catesbeiana) exposed to a mixture of trace elements during the embryonic and early larval periods. Physiol Zool 71:27-35. https://doi. org/10.1086/515885

Ruel JJ, Ayres MP (1999) Jensen's inequality predicts effects of environmental variation. Trends Ecol Evol 14:361-366. https://doi. org/10.1016/S0169-5347(99)01664-X

Ruthsatz K, Peck MA, Dausmann KH, Sabatino NM, Glos J (2018a) Patterns of temperature induced developmental plasticity in anuran larvae. J Them Biol 74:123-132. https://doi.org/10.1016/j. jtherbio.2018.03.005

Ruthsatz K, Dausmann KH, Drees C, Becker LI, Hartmann L, Reese J, Sabatino NM, Peck MA, Glos J (2018b) Altered thyroid hormone levels affect body condition at metamorphosis in larvae of Xenopus laevis. J Appl Toxicol 38:1416-1425. https://doi. org/10.1002/jat.3663

Ruthsatz K, Dausmann KH, Peck MA, Drees C, Sabatino NM, Becker LI, Glos J et al (2018c) Thyroid hormone levels and temperature during development alter thermal tolerance and energetics of Xenopus laevis larvae. Conserv Physiol 6:5coy09. https://doi. org/10.1093/conphys/coy059

Ruthsatz K, Dausmann KH, Reinhardt S, Robinson T, Sabatino NM, Peck MA, Glos J (2019) Endocrine disruption alters developmental energy allocation and performance in Rana temporaria. Integr Comp Biol. https://doi.org/10.1093/icb/icz041

Schaefer J, Ryan A (2006) Developmental plasticity in the thermal tolerance of zebrafish, Danio rerio. J Fish Biol 69:722-734. https ://doi.org/10.1111/j.1095-8649.2006.01145.x

Scott DE, Casey ED, Donovan MF, Lynch TK (2007) Amphibian lipid levels at metamorphosis correlate to post-metamorphic terrestrial survival. Oecologia 153:521-532. https://doi.org/10.1007/s0044 2-007-0755-6

Seebacher F, Franklin CE (2011) Physiology of invasion: cane toads are constrained by thermal effects on physiological mechanisms that support locomotor performance. J Exp Biol 214:1437-1444. https://doi.org/10.1242/jeb.053124

Seebacher F, White CR, Franklin CE (2015) Physiological plasticity increases resilience of ectothermic animals to climate change. Nat Climate Change 5:61. https://doi.org/10.1038/nclimate2457

Semlitsch RD, Caldwell JP (1982) Effects of density of growth, metamorphosis, and survivorship in larvae of Scaphiopus holbrooki. Ecology 63:905-911. https://doi.org/10.2307/1937230

Sheridan MA (1994) Regulation of lipid metabolism in poikilothermic vertebrates. Comp Biochem Physiol B 107:495-508. https://doi. org/10.1016/0305-0491(94)90176-7

Sheridan MA, Kao Y (1998) Regulation of metamorphosis-associated changes in the lipid metabolism of selected vertebrates. Am Zool 38:350-368. https://doi.org/10.1093/icb/38.2.350

Shi YB (2000) Amphibian metamorphosis. Wiley-Liss, New York

Smith DC (1987) Adult recruitment in chorus frogs: effects of size and date at metamorphosis. Ecology 68:344-350. https://doi. org/10.2307/1939265

Smith PN, Theodorakis CW, Anderson TA, Kendall RJ (2001) Preliminary assessment of perchlorate in ecological receptors at the Longhorn Army Ammunition Plant (LHAAP), Karnack, Texas. Ecotoxicology 10:305-313. https://doi.org/10.1023/A:10167 15502717

Smith-Gill SJ, Berven KA (1979) Predicting amphibian metamorphosis. Am Nat 113:563-585. https://doi.org/10.1086/283413

Ståhlberg F, Olsson M, Uller T (2001) Population divergence of developmental thermal optima in Swedish common frogs, Rana temporaria. J Evol Biol 14:755-762. https://doi.org/10.104 6/j.1420-9101.2001.00333.x

Steyermark AC, Miamen AG, Feghahati HS, Lewno AW (2005) Physiological and morphological correlates of among-individual variation in standard metabolic rate in the leopard frog Rana pipiens. J Exp Biol 208:1201-1208. https://doi.org/10.1242/jeb.01492

Stuart SN, Chanson JS, Cox NA, Young BE, Rodrigues ASL (2007) A comparison of the effectiveness of recommended doses of MS-222 (tricaine methanesulfonate) and Oraje ${ }^{\circledR}$ (benzocaine) for amphibian anesthesia. Herpetol Rev 38:63-66

Tata JR (2006) Amphibian metamorphosis as a model for the developmental actions of thyroid hormone. Mol Cell Endocrinol 246:10-20. https://doi.org/10.1016/j.mce.2005.11.024

Theisinger O, Berg W, Dausmann KH (2017) Compensation of thermal constraints along a natural environmental gradient in a Malagasy iguanid lizard (Oplurus quadrimaculatus). J Therm Biol 68:21-26. https://doi.org/10.1016/j.jtherbio.2017.01.005

Tietge JE, Holcombe GW, Flynn KM, Kosian PA, Korte JJ, Anderson LE, Degitz SJ et al (2005) Metamorphic inhibition of Xenopus laevis by sodium perchlorate: effects on development and thyroid histology. Environ Toxicol Chem 24:926-933. https://doi. org/10.1897/04-105R.1

Turriago JL, Parra CA, Bernal MH (2015) Upper thermal tolerance in anuran embryos and larvae at constant and variable peak temperatures. Can J Zool 93:267-272. https://doi.org/10.1139/ cjz-2014-0254

Van Allen BG, Briggs VS, McCoy MW, Vonesh JR (2010) Carry-over effects of the larval environment on post-metamorphic performance in two hylid frogs. Oecologia 164:891-898. https://doi. org/10.1007/s00442-010-1728-8

Wilbur HM (1977) Density-dependent aspects of growth and metamorphosis in Bufo americanus. Ecology 58:196-200. https://doi. org/10.2307/1935122

Wilbur HM (1980) Complex life cycles. Ann Rev Ecol Syst 11:67-93 
Yagi KT, Green DM (2016) Mechanisms of density-dependent growth and survival in larvae of Fowler's toad (Anaxyrus fowleri): volume vs abundance. Copeia 104:942-951. https://doi.org/10.1643/ CE-16-438

Yagi KT, Green DM (2017) Performance and movement in relation to post-metamorphic body size in pond breeding amphibian. $\mathrm{J}$ Herpetol 51:482-489. https://doi.org/10.1670/17-058
Yagi KT, Green DM (2018) Post-metamorphic carry-over effects in a complex life history: Behaviour and growth at two life stages in an amphibian, Anaxyrus fowleri. Copeia 106:77-85. https://doi. org/10.1643/CE-17-593

Publisher's Note Springer Nature remains neutral with regard to jurisdictional claims in published maps and institutional affiliations. 